Proceedings of the Prehistoric Society 85, 2019, pp. 1-27 (C) The Prehistoric Society. This is an Open Access article, distributed under the terms of the Creative Commons Attribution licence (http://creativecommons. org/licenses/by/4.0/), which permits unrestricted re-use, distribution, and reproduction in any medium, provided the original work is properly cited.

doi:10.1017/ppr.2019.7 First published online 19 August 2019

\title{
Bronze Age Beginnings - a Scalar View from the Global Outskirts
}

\author{
By HELLE VANDKILDE ${ }^{1}$
}

This article tracks the formation of the rich and socially complex Nordic Bronze Age (NBA), c. 2000-1500 BC, by applying a scalar methodology and using the entrepôt and early metalworking site of Pile in Scania as its point of departure. By regarding the Bronze Age as an ancient example of globalisation, Island Melanesia at the outskirts of contemporary globalisation is first examined to provide an analogue to the Nordic entrepreneurial and maritime culture into which metallurgy was first adopted. How did this northern margin become 'Bronze Age', and what impact did its inclusion have? Various scales, from local to Bronze-Age-global were found to intersect in the Pile hoard, and in similar sites near and far. By c. 2000 BC, metals and other commodities travelled along well-established local, regional, and super-regional networks, which even incorporated the British Isles and Unětician hubs at the Middle Elbe-Saale. Back in Scandinavia, metal and metal-related culture provided a comparative advantage when navigating local competition for influence and leadership. The transculturally global was strategically appropriated locally, using the reinvention of tradition as a principal strategy. The first metal boom caused friction and slow social change, rather than a social revolution. The real tipping point came in 1600-1500 BC, when the nearly full-blown NBA emerged, through engagement with a considerably expanded world. By this time, large amounts of metal were in circulation. Seen from the non-urban north, this unprecedented expansion of their world brought new opportunities but likely also deep social tensions. Thus, the effects of adopting metallurgy permeated society and connectivity at every level, even at the outskirts of the Bronze Age world.

Keywords: Bronze Age, metals, globalisation, tradition, multi-scalarity, connectivity, intersections, entrepôt, hubs, Scandinavia, Únětice, British Isles, inequality

In his presidential address to the Prehistoric Society in 1951, Christopher Hawkes presented his vision of a prehistory enriched by complementary scales of what he called para-history, proto-history, and tele-history (Hawkes 1954, 159-60). Although this proposition dimly recalls the Braudelian perception of history as layered into Evenement, Conjuncture, Longue Durée, and Economie-monde (cf. Bintliff 1991), it certainly anticipates recent efforts to conceptualise the deep past as essentially historical, as well as scalar (Shryock \& Smail 2012; Robb \& Pauketat 2013). Moreover, in keeping with Hawkes, the particular geographical

${ }^{1}$ School of Culture and Society, Department of Archaeology and Heritage Studies, Moesgaard Allé 20, building 4215, 132, 8270 Højbjerg, Denmark. Email: farkhv@cas.au.dk perspective is deemed significant, notably, whether the analytical point of departure is the urban south or the non-urban north of later prehistory (cf. Hawkes 1954).

This article is based on my Europa 2017 lecture to the Prehistoric Society and takes a modernised Hawkesian view of the Bronze Age. My aim is to more precisely track the formation of the Nordic Bronze Age (NBA) from its embryonic beginning around 2000 BC to its breakthrough c. 1600-1500 BC. I do this by zooming in and out between significant temporal-geographical scales, from the Nordic local to the Eurasian global. Such a scalar approach to cultural change is prompted by globalisation theory, and by looking at the variability of the Bronze Age as 'global local', meaning that the global permeates the local in various ways. 
Recently, the Bronze Age has been compared to the globalised state of the contemporary world (Vandkilde 2016; 2017a; 2017b). In this perspective, the Bronze Age is a period of pre-modern globalisation driven specifically by the use of bronze (or similar metals with similar properties). The concept of bronzisation (ibid.) has been formulated to identify the processes involved in establishing the Bronze Age as a historical phenomenon: 'bronzisation' is defined as bronze-led, multi-scalar connectivity across tracts of Afro-Eurasia. This puts bronze centre stage as the first artificial substance, a unique alloy that may have been similarly valued, if variously used, by diverse cultures during the Bronze Age (Wengrow 2011). Despite the Scandinavian perspective presented below, it should be emphasised that any place or region within the Bronze Age hyper-region was likely to reflect glocality in its being and doings, meaning that it was simultaneously local and global, with due consideration given to the relational levels between these.

The recently investigated coastal site and hoard of Pile in Scania marks the starting point, c. 2000 $\mathrm{BC}$, of the first durable local metallurgy in Southern Scandinavia. Several worlds, neighbouring and distant, intersect in the hoard with its string of extraordinary metal objects. Together this collection offers considerable potential to unveil the significance of the site itself and, indeed, the scalar connectivity coming into existence at the onset of the Afro-Eurasian Bronze Age, around 2000 BC. This requires shifting back and forth between the minimal perspective of the local, and the broader regional and hyper-regional realities of the Early Bronze Age. Thus, this study seeks to track and make sense of developments that led to the seminal Middle Bronze Age threshold, c. 1600-1500 BC (cf. Vandkilde 2014a; 2017a). A scalar methodology helps to substantiate the connectivity at several intersecting levels, and the underlying socio-economic processes, notably, the question of how social inequality arose in the wake of 'becoming metallurgical'. Although it is agreed that some form of social inequality emerged in Southern Scandinavia at some point between 2000 and $1500 \mathrm{BC}$, the greater challenge is to unveil its character and development against the back-drop of high mobility and cultural diversity (eg, Haak et al. 2015; Kristiansen \& Suchowska-Ducke 2015; Vandkilde et al. 2015; Nørgaard et al. 2019). Data from contemporary Island Melanesians may help to clarify this question of emerging social inequality.

The study has four linked parts. First, the state of the art is concisely reviewed in terms of globalisation theory and drawing on recent publications (Vandkilde 2016; 2017a; 2017b). Second, an excursus is made to contemporary Island Papua New Guinea (PNG), which relies on data I collected during fieldwork in 2007. The PNG case study functions as a relational analogue (Wylie 1985) to the Scanian case study, in particular. Both areas are at the outskirts of ongoing globalisation. Nevertheless, individuals and communities are responding strategically to global flows, while becoming drawn into processes that are partly beyond their control. This threatens to transform rooted social traditions and life worlds. Third, armed with theoretical and anthropological insights, the analytical focus moves to the key site of Pile in Scania 2000 BC, where an entwined history is revealed by gradually enlarging the geographical scale to include Western and Central Europe. This shows how the socio-economic effects of tight bronze-led connectivity permeated society at every level, even at the outskirts of the Bronze Age world. Similarly, the timeline is followed to the breakthrough of the Middle Bronze Age, when substantial changes occurred. Fourth, the Bronze Age as pre-modern globalisation with synchronised thresholds is evaluated as a platform for briefly reflecting on past and present globalisation.

\section{THE BRONZE AGE AS PRE-MODERN GLOBALISATION}

Known from trillions of archaeological finds, the Bronze Age covered a hyper-region of Afro-Eurasia that reached from China to the Atlantic brim, and from Scandinavia to India (Fig. 1). The Bronze Age world was more tightly interlinked than the Neolithic and the Chalcolithic periods, and the geographical extent of the connectivity was also far greater (Vandkilde 2016; 2017b). Nevertheless, the question is how this increased connectivity was structured.

In contrast to the prevailing scholarship that regards the Bronze Age as consisting of centres with dependent peripheries, Kohl wrote in 2011 (77, 81) that Bronze Age linkages do not appear onedimensional or classifiable into a world-system order (sensu Wallerstein 1974). Instead, he described Bronze Age connectivity as amorphous and web-like, with periodically expanding fields of social interaction. This view is in tune with the multi-scalar view favoured here, with the note that at times, political and military power may well have had an impact, especially on the long-distance interactions we find in complex societies (cf. Earle 2002). If the Bronze Age was not primarily a world system, it may have 


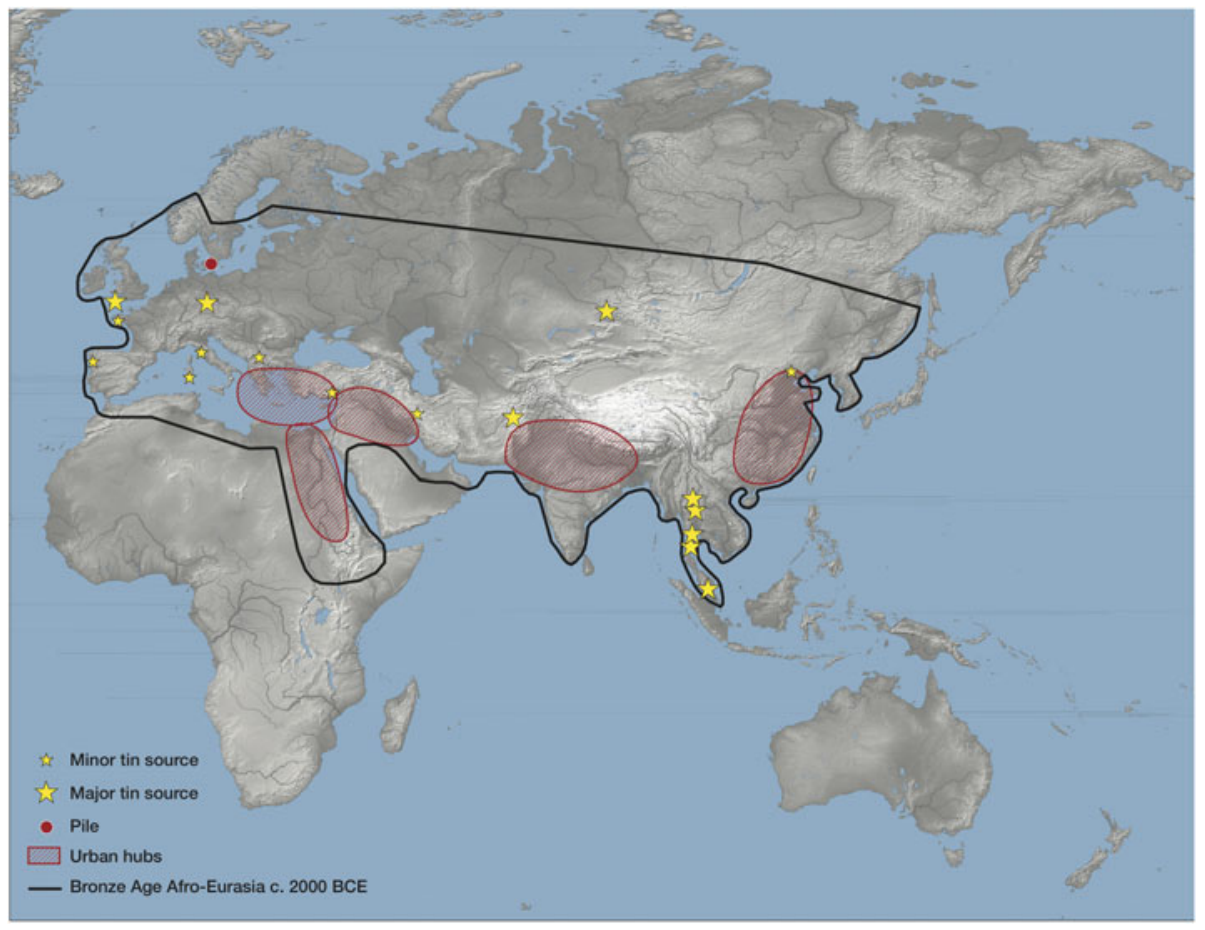

Fig. 1.

The Bronze Age hyper-region, with Pile in the far north-west corner, was composed of trans-regional systems which intersected and were regularly traversed. Considerable cross-zone movement was necessary for obtaining bronze, as tin and copper ores are not equally distributed over the Bronze Age hyper-region. Bronze and metal with similar properties were game changers. In the Neolithic and Chalcolithic, copper was only variably known, socially restricted, and exchanged as an exotic prestige good. Two traversing Bronze Age linkages are discernible: 1. east-west links: a proto-Silk Road travelled by pastoral nomads (Wilkinson 2014); 2. north-south links: between the urban and non-urban zones (after Vandkilde 2017a, 179, fig. 104; graphics by Unit of Archaeological IT AU Moesgaard)

had more in common with the multi-layered and changeable connectivity of our own time, hence its identification as pre-modern globalisation. Other analogues appear among globalising phenomena in the ancient world, which, on the one hand, reveal intensified long-distance interaction, and on the other hand, suggest social changes linked to the development of global culture (Jennings 2011, 33-4). Compared to other ancient globalisations, however, the Bronze Age appears inherently networked, connected to bronze and other commodities, and with a multiscalar structure disclosing intermeshed local, regional, and superregional levels of interaction (Fig. 2).

Considering the forms of transport and mobility systems (sensu Urry 2007) available in the Bronze Age, the vast geography of Afro-Eurasia cannot have been routinely traversed. Instead, interaction was mostly confined to trans-regional configurations, which I here propose to regard as intersecting spheres of interaction that changed over the centuries of this period, as they expanded or shrank. The outlines of these configurations are known for earliest Bronze Age Scandinavia (Fig. 3), whilst the Mediterranean region, for example, may be similarly understood (cf. Broodbank 2013; Bevan 2010). Instead of centres and peripheries, spheres of interaction may have underlain Bronze Age connectivity, especially if the intersections of their parts are recognised as the engine driving the far-reaching spread of tangible and intangible novelties, including that revolutionary new substance, bronze. Taken together, these make the Bronze Age historically unique. In the model (Fig. 3), these specific intersections are crucial repositories of cultural and economic knowledge that stem from, and are accessible to, distant places. This may be seen as the structural principle underlying efficient movement over wide distances: in this way, intersecting spheres of interaction are Bronze Age versions of Histoire Croisee (Werner \& Zimmermann 2006). 


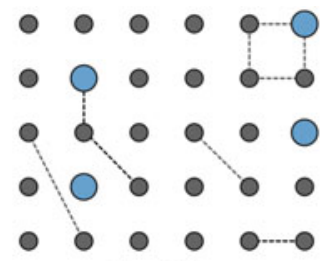

Neolithic:

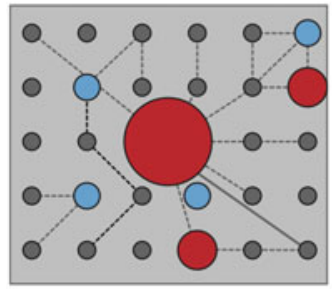

Bronze Age: Global Culture Pre-Globalization
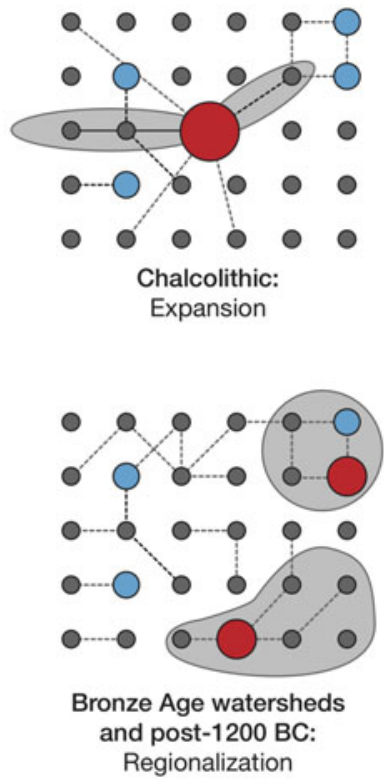

Regionalization
Fig. 2.

Jennings' four-phase model of ancient globalisation (2011), tentatively correlated to prehistory. The Global Culture phase matches the Bronze Age, with differently-sized competing hubs in a tightly networked setting of numerous communities linked by flows of people, objects, or ideas (redrawn with additions to the original model after Jennings 2011, 37, fig. 3.1)

The Bronze Age became established around 21002000 BC, when copper-based metallurgy entered local practices across the Afro-Eurasian hyper-region, even if it did not involve an even spread of either the metal or the technology supporting it. A marked growth in bronze-related practices, from mining to consumption, occurred in many places around $1600 \mathrm{BC}$, following a drawn-out crisis. These two watersheds are in focus below. Around 1200 BC, the Bronze Age world began to shrink, probably as a result of a transformation that had been under way for some time. The Urnfield expansion and the collapse of the palatial polities in the west of the urban south (eg, Cline 2014) are explicit signs that the Bronze Age world was coming to an end. However, for over 800 years, the Bronze Age existed as a unique case of pre-industrial connectivity, involving a networked scalar complexity led by a desire for bronze, and maintained by innumerable interconnections within and across spheres of interaction.

The Bronze Age is remarkable as the largest of the early interconnectivities, especially considering that it was not driven by empires' ambitions and conquests.
Instead, economic growth and porous boundaries fuelled the increasing availability of bronze, no doubt with a parallel trend of rising inequality. The Bronze Age hyper-region held countless different peoples, cultures, and languages. There were several centres of civilisation whose ambitions, rivalry, warfare, or trade impacted Bronze Age connectivity, but none was the sole factor driving it. Very different subsistence economies were at work, such as varied forms of agriculture infused with animal husbandry in large parts of non-Mediterranean Europe, irrigation agriculture in the urban hubs, a resilient mixed economy in the Mediterranean, although pastoralism prevailed in those huge tracts that connected the east and west of the hyper-region. Clearly, bronze-spread transcended all this diversity, showing limited respect for boundaries.

It is worth noting that in East Asia the Bronze Age was different from elsewhere, but there is still common ground, for example in the swords, socketed spearheads, war chariots, and even state formation (eg, Cunliffe 2015; Linduff et al. 2018). In China, copper and tin may have come from the Urals and Altai, through the Ganzu corridor, together with the first chariots: the Seima-Turbino metalworking complex may have acted as intermediary between East and West (eg, Franchetti 2008; Wilkinson 2014; Cunliffe 2015). Similarly, in the West, differences are often noted between the ways Bronze Age culture was organised in the urban south and in the nonurban north (eg, Kristiansen 1998). Nevertheless, reducing the cross-linkages to a system of centres and peripheries is problematic. In several cases, innovations moved from north to south: bronze technology was already very present in Britain prior to $2200 \mathrm{BC}$, which may well have been the major point of dispersal to other parts of the hyper-region (cf. Rassmann 2010; Needham 2017). The lightwheeled chariot spread in all directions from Sintashta, in the Urals (Anthony 2007; Cunliffe 2015). The particular appearance and wealth of the NBA is remarkable, since every bit of metal was imported to the region throughout the long Bronze Age. This is also unexplainable in terms of dependence on Aegean or other hubs, even if commodities and luxuries with added value certainly travelled long distances, and in both directions (eg, Kristiansen \& Larsson 2005; Czebreszuk 2007; Needham \& Giardino 2008; Maran 2013; Kaul 2013; Vandkilde 2014a).

Current globalisation is maintained by incessant flows of transculture, including people, circulating 
(a)

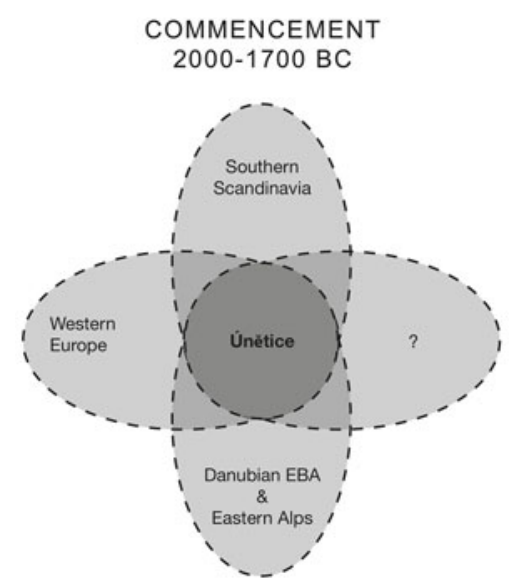

(b)

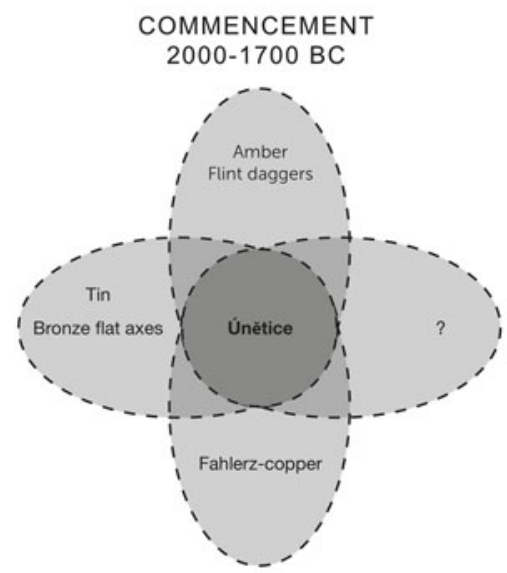

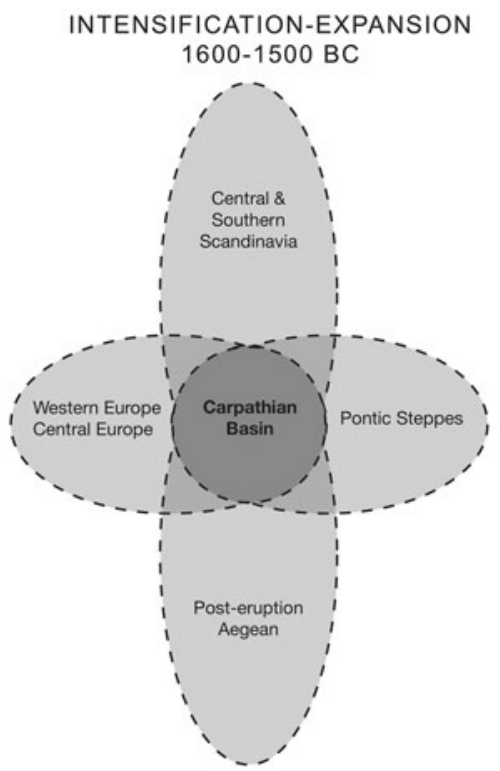

INTENSIFICATION-EXPANSION 1600-1500 BC

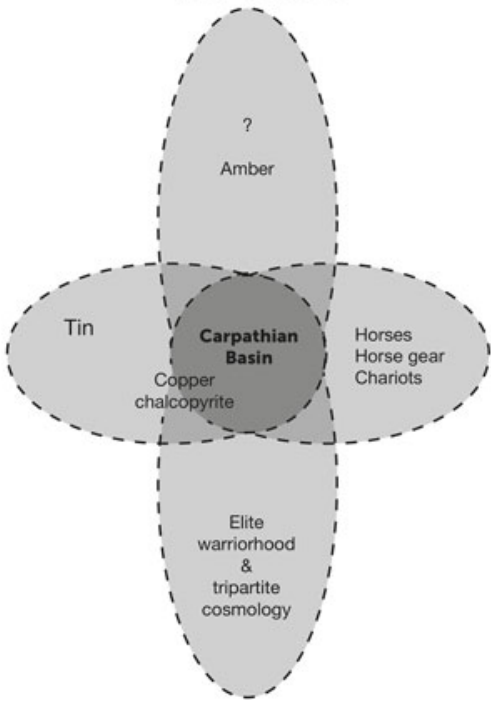

Fig. 3.

The model of intersecting spheres of interaction, as it may have looked: a) in the EBA 2100-1600 BC; and b) in the early MBA, around 1600-1500 BC. C Helle Vandkilde

between the local and the global levels. Cross-border mobility rates are very high, which expedites unprecedented techno-economic growth (Urry 2007; Inda \& Rosaldo 2008; Appadurai 2010). There is an increasing democratisation of transcultural resources, along with ongoing local appropriation. Nonetheless, social inequality is on the rise along with friction and vulnerability at societal and inter-societal levels (eg, Friedman 1994; 2006; Tsing 2004). Although the scale is very different, these characteristics appear recognisable from far earlier in the Bronze Age (Vandkilde 2016; 2017b).

Bronze - or other metal with similar properties was the glue that linked Bronze Age societies, whether they were situated near each other or were farther apart. Bronze is broadly comparable to today's oil, 
petrol, and money. However, its tremendous potential, and its colour and pliability made bronze so much more than merely an indispensable commodity. Bronze relativised local culture as it travelled: it disrupted regional systems, along with an array of luxury goods: woollen textiles, spices, salt, horses, blue glass, amber, lapis lazuli, silver, gold, and even silk. Long-distance directional transport of commodities took place alongside situated appropriations of these international goods, which were transformed, recycled, and exchanged locally. Such a scalar and appropriative process, which ultimately depends on routinised transport, is especially clear with regard to copper (Needham \& Giardino 2008; Ling et al. 2014; Radivojević et al. 2018; Nørgaard et al. 2019). Ships better equipped for long-range transport were developed, such as the Hjortspring-type Nordic plank-built long-ships, which appeared with the onset of the NBA (eg, Ling 2008; Vandkilde 2014a; Ling et al. 2015; 2018). Spoke-wheeled vehicles may have enhanced land transport, along with improved knowledge of how to navigate at sea, on land, and along rivers. By analogy with the effective mobility systems of our own time, this may have affected a feeling of 'time compression' and some sense of a 'global state of mind' among those who travelled.

The Bronze Age saw the growth of several technoeconomic sectors, and innovations linked to the disruptive technology of bronze, fuelled by marked demographic expansion (Müller \& Diachenko 2019). This entanglement may be envisioned as a positive feedback loop of technology, demography, and economy, which introduced new crops, improved tools, efficient landscape organisations, better mobility systems, and the military inventions that were also strongly in evidence (cf. Vandkilde 2016; 2017b). Over time, bronze became more accessible and commonly used throughout several societal sectors, although it tended to simultaneously expedite social inequality, visible, for example, in the conspicuous consumption invested in burials and hoards. Last but not least, the Bronze Age had a lengthy history of both gradual change and disruptive thresholds. Permeable borders and the networked intricacy that characterised the period no doubt made societies and people vulnerable to any crisis that could also easily spread. Bronze Age communities captured in a state of social friction is far from unlikely (cf. Tsing 2004). One might think of followers of tradition opposing the followers of innovation at one end of the scale, whereas more clear-cut divides between the privileged 'haves' and the unprivileged 'have nots' would have inhabited the other end of the scale (cf. Ling et al. 2018). In the first case, reinventing a rooted tradition might be a likely compromise or overt strategy used by leading entrepreneurs. In the second case, my expectation would be to find more rigid divisions of access to wealth and culture.

\section{ISLAND MELANESIA: VISITING THE OUTSKIRTS OF CONTEMPORARY GLOBALISATION}

Despite their dissimilar histories, contemporary Island Melanesia offers clues to how bronzisation may have impacted non-urban Southern Scandinavia around 2000 BC. The entrepreneurial spirit and maritime setting of the Manus province of PNG generally matches the Nordic Late Neolithic culture that first adopted metallurgy (cf. Apel 2001; cf. Sahlins 2005; Skoglund 2009; Vandkilde 2007; 2017a; Olausson 2013). Manus is far from globalised cities; the nearest is the capital of Moresby, with its multiple opportunities alongside deep and growing social tensions (Windybank \& Manning 2003). Lorengau, the provincial capital of Manus, is an intermediate hub, which has both prospects and problems on a smaller scale, as air and sea traffic connect it directly to Moresby. Moreover, Lorengau is the main maritime hub for numerous remote islands spread across the Pacific archipelago south of Manus Island. Small open speedboats are today the main travel option and timesaving compared to the traditional outrigger canoes. These different places, and scalar levels of geography from the local and regional to the urban global, intersect through the movement of people, money, goods, and global life styles. Each shows varying ways of receiving the transculturally global, and their specific cultural backgrounds also vary.

The islands of Baluan and Mbuke are located four to five speedboat hours away from one another and from the Lorengau hub. The adoption of the global differs on these two islands, probably determined by local geography and history. In many ways, the traditional Melanesian culture still remains, essentially as described by Mead a century ago $(1930 ; 1956)$. The rather large and fertile agricultural island of Baluan maintains it strong traditions, but also innovates on it through the global. The reinvention of tradition is a new strategy, often materialising as a hybrid of local and global culture (Hobsbawm \& Ranger 1983; Otto $\&$ Pedersen 2005). The rocky and much smaller 
Mbuke is an island that subsists on maritime trade, and the sea captains are still renowned as the expert intermediary traders who connect remote islands with each other and with the hub of Lorengau; indeed, they are Mead's 'Middle Men' (1930). Here, tradition nowadays is embedded, rather than strategically manipulated, and islanders easily switch into a 'global mode'. On both islands, tradition today is recognisable in the outrigger canoes, the institution of captainship and lapans (big men), pillared houses built in the shallow beach-near water, and the ceremonial exchange of betel nuts, bananas, and pigs. For most people, transcultural goods are restricted to low-tech consumer commodities (eg, coffee and rice) acquired through speedboat trips to and from Lorengau, and available for purchase in the small local stores. There is an emerging rich-man-poor-man divide determined by whether or not households receive extra income from expatriate family members.

Expatriate Papua New Guineans are those who can afford to leave the islands for education, jobs, business, and regional or national politics. They send back money, but rarely visit their home island. When they do, they flaunt high-tech global culture (eg, mobile phones) and contribute to a growing inequality, but their input fuels the economy and provides modern facilities in a harsh island setting. In contrast, repatriates, with their oversize speedboats, huge houses, and high-tech goods, are perhaps the real game changers, as they return on a more permanent basis, armed with political ambitions and cultural and economic capital earned in Moresby or in Australian urban hubs, such as Cairns. These developments challenge the rooted tradition of self-governance through kinship and the social rivalry of male heads of certain successful lineages. The Big Man institution is intrinsic to these islands, richly described in the scholarly literature as built on entrepreneurship and non-profit reciprocal exchange (eg, Malinowski 1922; Mead 1930; 1956; Spriggs 1997; Sahlins 2005; Otto 2006). The Big Man is still in place, and he inhabits a traditional Big Man house that differs from normal houses only in its courtyard for public feasts and ceremonial exchanges, not much different from what Mead observed in the 1920-30s (1930; 1956).

Alongside the old-style Big Man, repatriate entrepreneurs now interfere in the social rivalry for leadership with their accumulated global resources. These 'repats' are outsiders in the sense that they may lack the proper lineage and the deep knowledge of tradition usually required to gain local support for candidature. Instead, they are skilled at reinventing tradition by combining new and old ways, such as investing in culture festivals and oversize 'Big-Man houses', built according to traditional architecture but strongly geared with high-tech facilities, from bathrooms and kitchens to computers and satellite phones. As outsiders, repats are able to continue accumulating wealth without the traditional obligation to reciprocate: they do not have to redistribute it all to followers. In this way, friction (Tsing 2004) between supporters of the old and new ways may coincide with other emerging divides between richer and poorer, stimulated by global flows in general and by the return flow of individuals who did not make it in the city.

It is an open question whether the PNG island communities are becoming divided by class and whether leadership is emerging as an institution defined by ability to accumulate wealth. Some trends, cited above, may be so interpreted. Although Melanesian society is under pressure from globalisation, change here is a long process, not an overnight revolution. Tradition is remarkably resilient, as Sahlins wrote in his 'develop-man paper' (2005). In the words of Ricardo (1817), global goods offer ambitious outsiders a clear comparative advantage, but success may ultimately depend on these global proponents' ability to navigate the complexity of cultural tradition. Friction seems to be growing, but this factor seems to exist primarily at a structural level, in the rising differences between rich and poor.

What may be learnt from Island Melanesia? First, incorporation into a global reality changes the rules of the game in multiple ways, notably by equipping particular persons with advantages on the local stage, thanks to the valuables and knowledge they accrue in the years spent at global hubs. This means that globalisation may put existing leadership forms under pressure. Second, tradition is a strong force to contend with, and not easily changed. When enriched with the transculturally novel, the border between the traditional and the global becomes blurred, but radical change still does not seem to be around the next corner. Third, responses to the global may vary, even within a small and tightly-knit region, because tradition is typically not a constant either. Fourth, although transculture becomes more common over time, even in the remotest locations, this democratisation of desired resources is countered by rising 
inequality. The associated friction is a structural outcome of ongoing globalisation. Lower-class developments are particularly distinct in the hubs, due to immigration, but are an increasing presence in the global outskirts, just as in the rest of the world.

PILE IN SCANIA 2000 BC: EMERGING BRONZISATION ON THE OUTSKIRTS OF THE BRONZE AGE WORLD

Pile is located in the southern Swedish province of Scania, immediately south of Malmö City right on the coast of Öresund, and with easy access to the Baltic Sea and distant lands (Fig. 4). The metal hoard with its $c .30$ objects was discovered in 1864 and was immediately dispatched to Stockholm, owing to the spectacular character of the items. Montelius (1880) published a description of the hoard in a short notice, and this assemblage of early metal items has since been a principal thread in discussions about NBA beginnings (Vandkilde 2017a, 55-9). Simply stated, this hoard is the first, finest, and one of the largest in a long series of rich Nordic wetland deposits from the Bronze Age.

Briefly, the importance of Pile is that the site of the hoard reveals connections to both near and distant places during the critical phase at the beginning of the Bronze Age, c. 2000 BC: in this perspective, Pile is a seaport, an entrepôt. There were several similar seaports along the Scanian and Danish coasts. Like Pile, such sites may well have been metalworking sites. The dating of Pile to c. $2000 \mathrm{BC}$ is typology-based and consistent with the predominance of tin-poor copper (rather than bronze proper). The hoard content belongs to the early stage of both the Nordic and classic Únětician hoard sequences, which correlate with radiocarbon dates of c. 2100/2000-1700 BC (Vandkilde 2017a, 109-22). The hoard offers an exceptional opportunity for inquiring into the first enduring metallurgy and its broader impact at scales from local to global. Pushed by a rising demand for the novel metal, European connectivity at this time was increasing significantly, and Pile was a contributor to, and a sign and even a symbol of, this change at the edge of the Bronze Age world.

\section{Five worlds intersect at Pile}

Five worlds intersect in the Pile hoard (Fig. 5). This intersection recurs at other geographical scales: locally in Scania, regionally in Southern Scandinavia, and additionally reaching super-regionally deep into central Europe and westward to the British Isles (cf. Fig. 3). The hoard itself comprises a group of 12 low-flanged axes of so-called Pile type, a class of axe that occurs quite frequently in Southern Scandinavia, mostly deposited singly from 2000-1700 BC. They were made locally at sites such as Pile. Local and regional cross-links are strongly indicated by the fact that these early axes are similarly made, following a specific Nordic tradition that integrates characteristics of British and Únětician axes. One may then perhaps classify the Pile-type axes as hybrids in an initial phase of bronzisation, but they are also local products with their own unmistakable stylistic expression.

In the Pile hoard, the Nordic world effectively intersects with more distant worlds. A large, developed bronze flat axe of the Ballyvalley type (or Falkland, Scrabo Hill, Glenalla, or similar) brings the British Isles distinctly into the picture. However, the most comprehensive of the intersections is the Unertician intersociety, which covered large parts of Middle Europe, as far as the Baltic Sea. The now-lost silver spiral, the ribbed bracelet, the large, solid noppenring, and the bevelled blutegel-ring all derive from the Circum-Harz hub at the Middle Elbe-Saale. However, the two oval arm rings (one with ribbed ends), the dagger blades, and metal-hilted daggers are more northern products, presumably made in Mecklenburg. The long-dagger is probably the largest known, its estimated original length nearly $30 \mathrm{~cm}$. The most distant of the lands encountered at Pile is the Eastern Alps, including the Danubian EBA culture, since the $\mathrm{C}$-shaped rings and the three ingot fragments from ösenhalsrings derive from this region (Vandkilde 2017a, 131, fig. 72). Overall, this is a remarkable collection of objects. Indeed, different worlds meet at the Scanian coastal site of Pile, displaying a scalar connectivity from the place of Pile to the global far-away, namely central Europe and the British Isles (Fig. 6).

Trace-element analysis of the metal and lead isotopy confirm the foregoing conclusions and reveal significant details. The British axe is made of a nonfahlore, low-impurity copper that corresponds closely to the distinct group of Scandinavian-found British axes. The metal of the axe from Pile matches the Alderley Edge mine in Cheshire (Stos-Gale 2017a; Vandkilde 2017a, 133-43). This axe is the only high-tin item in the hoard, which contains predominantly copper objects with traces, or small amounts, of tin. It is not unlikely that the imported British axes, 


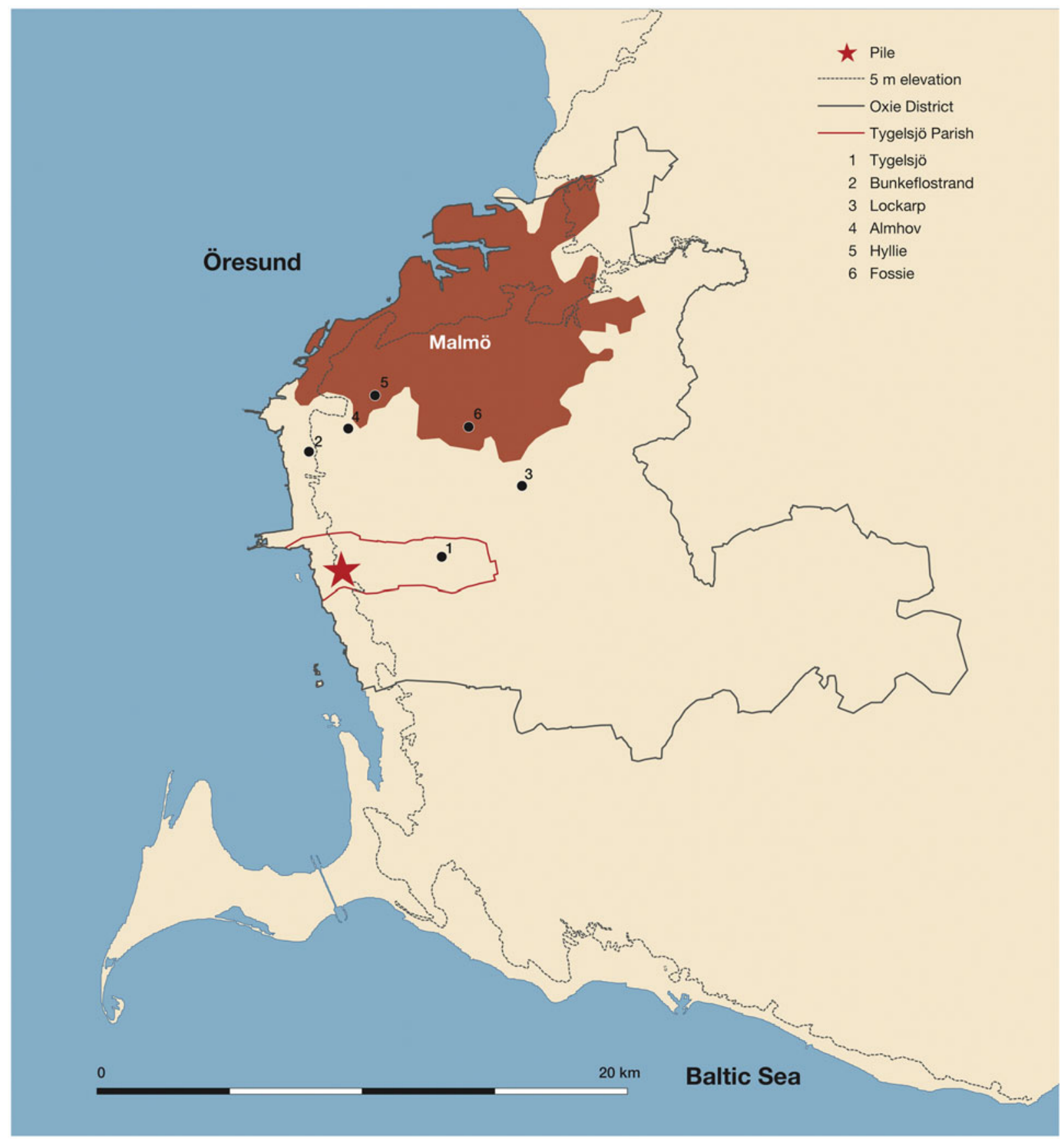

Fig. 4.

The location of Pile in south-west Scania, c. $200 \mathrm{~m}$ from the ancient coastline of the Öresund Strait, leading to the Danish isles, or farther southward or westward (after Vandkilde 2017a, 23, fig. 6; graphics by Unit of Archaeological IT AU Moesgaard)

apart from their attractive size, golden colour, and intriguing ornaments, were understood as a way to enrich the local production with tin.
The rest of the copper from Pile stems from the Eastern Alps. The so-called Ösenring Kupfer was the most significant of the three fahlore copper types 

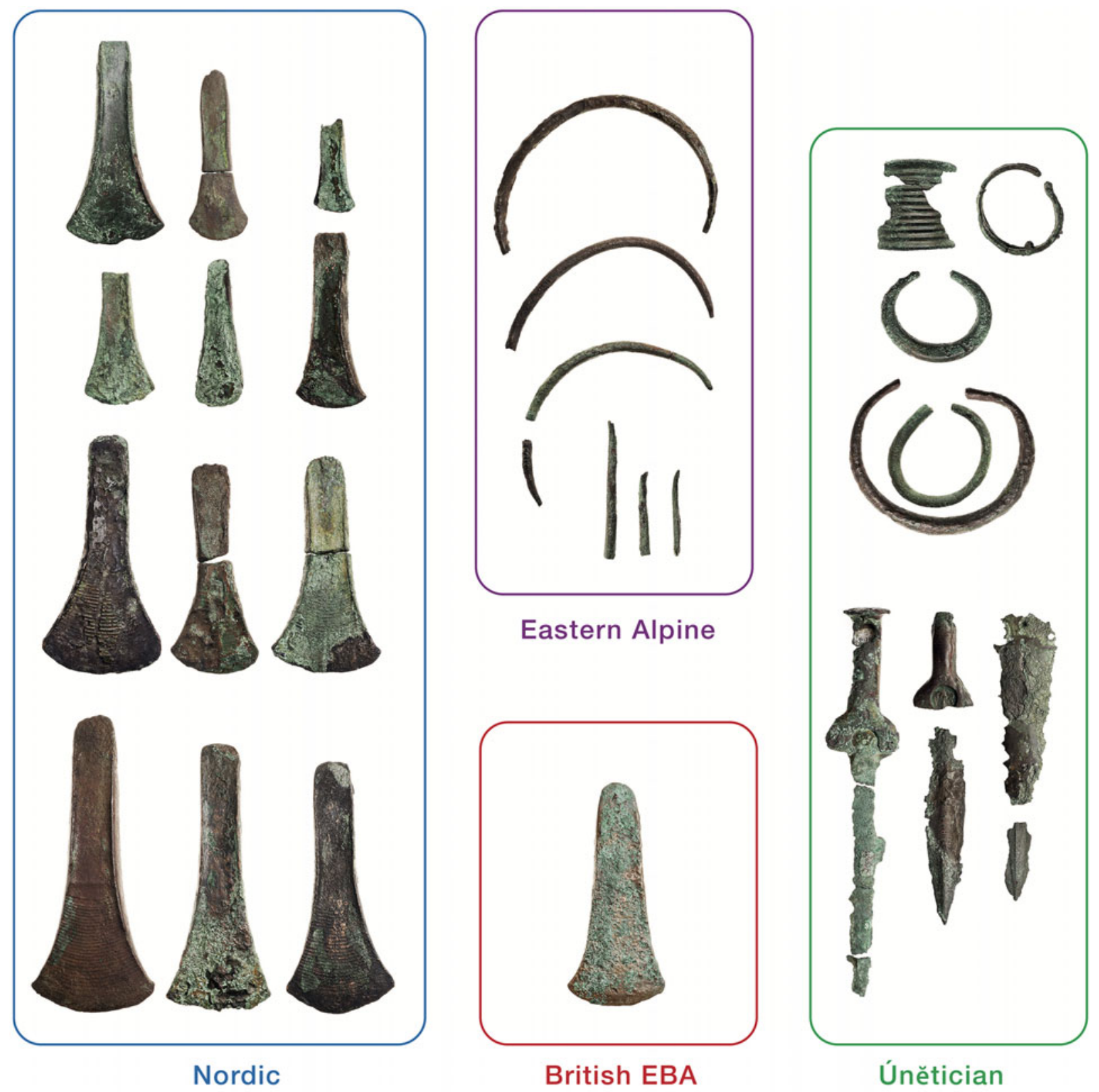

Fig. 5.

The Pile hoard with its four groups of metal items with different provenance: Nordic, British, Únětice, and East Alpine. The Únětice group includes objects from the Mecklenburg coastland and from the hub at the Middle Elbe-Saale. The copper probably came from the eastern Alps (Inn valley), the only exception being the British-developed bronze flat axe, which may be traced to the Alderley Edge Mine in Cheshire, through isotopic signatures. This axe is the only high-tin object (C) Helle Vandkilde, photo: Ola Myrin, The Swedish History Museum)

used at Pile at this early date. Ösenring copper were transported across wide tracts of Europe in the shape of ösenhalsrings (Krause \& Pernicka 1998; Krause 2003). Likely mined in the Inn valley of Austria
(Nørgaard et al. 2019), this ösenring copper, extremely low in nickel $(\mathrm{Ni})$, is predominant in the Pile assemblage. This is followed by a second copper that looked much like the ösenring copper but had 


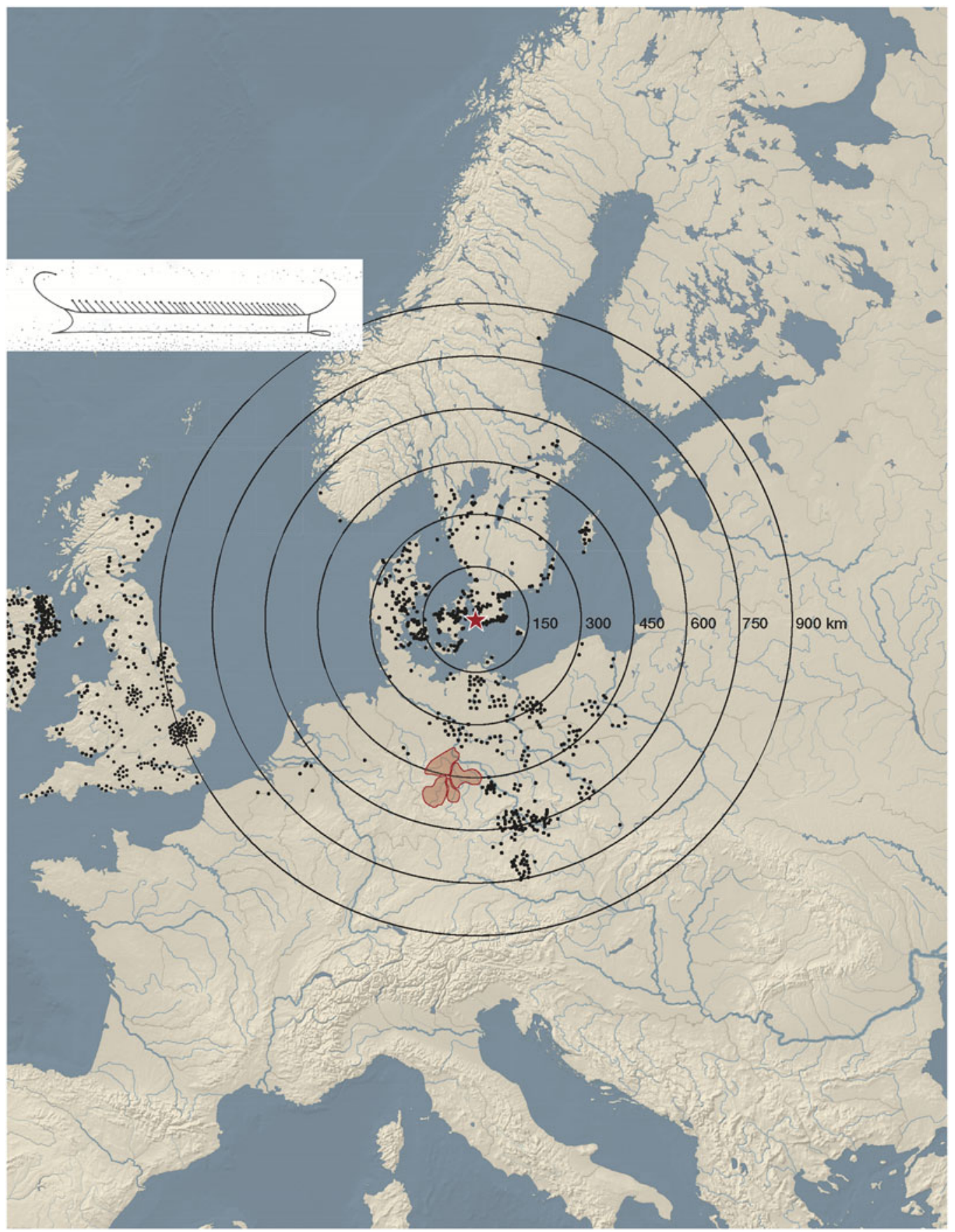

Fig. 6.

Model for scaling up or down. Pile is shown as a point of departure for travelling short or long distances at sea. It would take three to seven days to reach Fünen, Rügen in Mecklenburg-Vorpommern, or northern Scania. It would take 20-40 days to reach the Isle of Thanet, or the central Únětice hub, in the latter case, river-riding for most of the journey. A prototype of the Rørby ship (depicted on the $c .1600$ BC scimitar found on north-west Sealand) may have expedited the ability to travel greater distances at sea (eg, Vandkilde 2014b) (after Vandkilde 2017a, 162, fig. 101; graphics by Unit of Archaeological IT AU Moesgaard) 


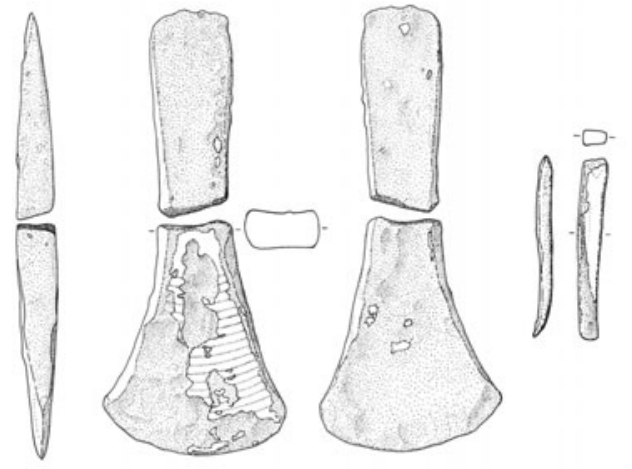

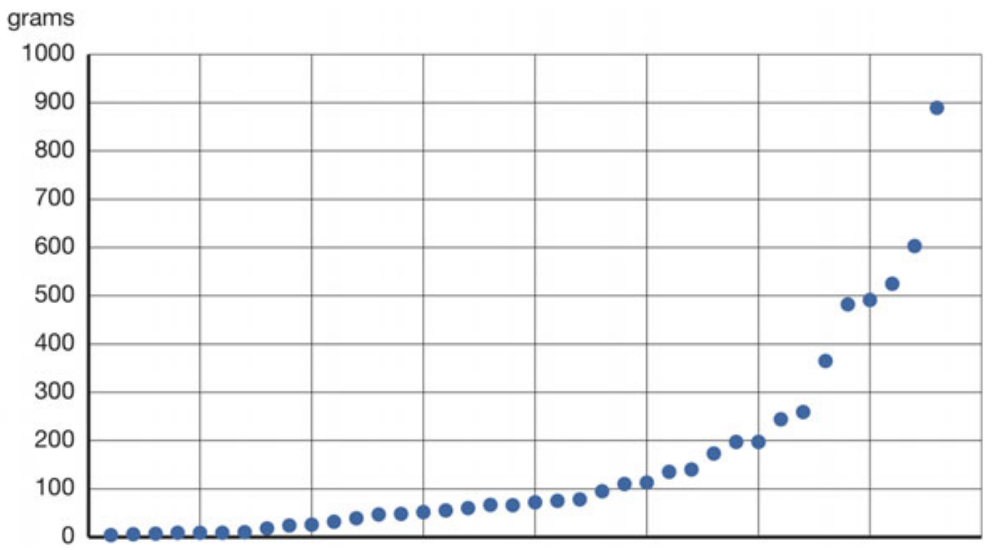

Fig. 7.

There is extensive deliberate fragmentation in the hoard. This broken metal was recycled into new items, mostly the lowflanged axes, one-third of which feature multi-lined decoration on the cutting-edge; these so-called Pile-type axes were the benchmark of the earliest Nordic metalwork production (after Vandkilde 2017a, 127, fig. 70, 72, fig. 40A, 103, fig. 59A)

slightly higher Ni levels. The third copper has high presence of all four indicators $(\mathrm{Ni}, \mathrm{Ag}, \mathrm{Sb}, \mathrm{As})$ (Vandkilde 2017a, 134-6, figs 76, 79). This array of three related types of fahlore copper is similar to the situation in the Unětice region, which suggests that this region played a key role. When the available typological and metallurgical evidence is combined, it is fairly clear that the Unětice region functioned as an intermediary, a mediator, of fahlore copper to Scandinavia. The alternative of a direct trading link between the Alps and Scandinavia is less plausible, especially because ösenhalsrings are quite commonly hoarded at the Middle Elbe-Saale, despite the fact that they were manufactured in the Eastern AlpineDanubian region (Krause \& Pernicka 1998; Krause 2003; Vandkilde 2017a, 133-51).

\section{Early Metalworking at Pile and in Southern Scandinavia 2000-1700 BC}

Despite the overall absence of waste slag, melting droplets, and crucibles, the Pile hoard provides the first unmistakable evidence that metalworking had already begun in Southern Scandinavia around 2000 BC. The substantial and varied breakage of objects, apparently not primarily ritually motivated, is a clear sign that metalworking was carried out near the place where this extraordinary assemblage was deposited. Most of the items at Pile are hacked into pieces to fit a crucible: four of the axes were broken by heating and sheer force, whereas the pieces of ösenrings are broken and substantially hammered (Fig. 7). Small differences in the otherwise similar copper compositions in Scandinavia and in the Unertice area sustain the impression of the ongoing mixing of the metal at hand; indirect evidence of local metalworking in Scandinavia (Vandkilde 2017a, 137-43).

At Pile and other contemporaneous hoard sites in Southern Scandinavia, metal composition is clearly grouped into the same three fahlore types. This condensed distribution of major trace elements in the hoards is opposed to the wider dispersal of trace elements in the general dataset of $c .300$ metal analyses of objects from the period 2000-1700 BC (Fig. 8). This may demonstrate that each hoard represents a thin time slice of freshly arrived metal. Nonetheless, the hoards illustrate a close relationship, especially between the two related types of low-nickel copper, which suggests that metalworking and mixing of coppers began soon after arrival of the metal. Real ingots did not exist; instead, old objects and failed casts were recycled. In effect, in Southern Scandinavia, copper from different mines, or sections of these mines, were mixed during the process of metalworking. The data suggests frequent incoming loads of fresh copper, and also degrees of recycling of this copper. The hoards seem to have been deposited fairly soon after their arrival, before more substantial recycling could take place. 


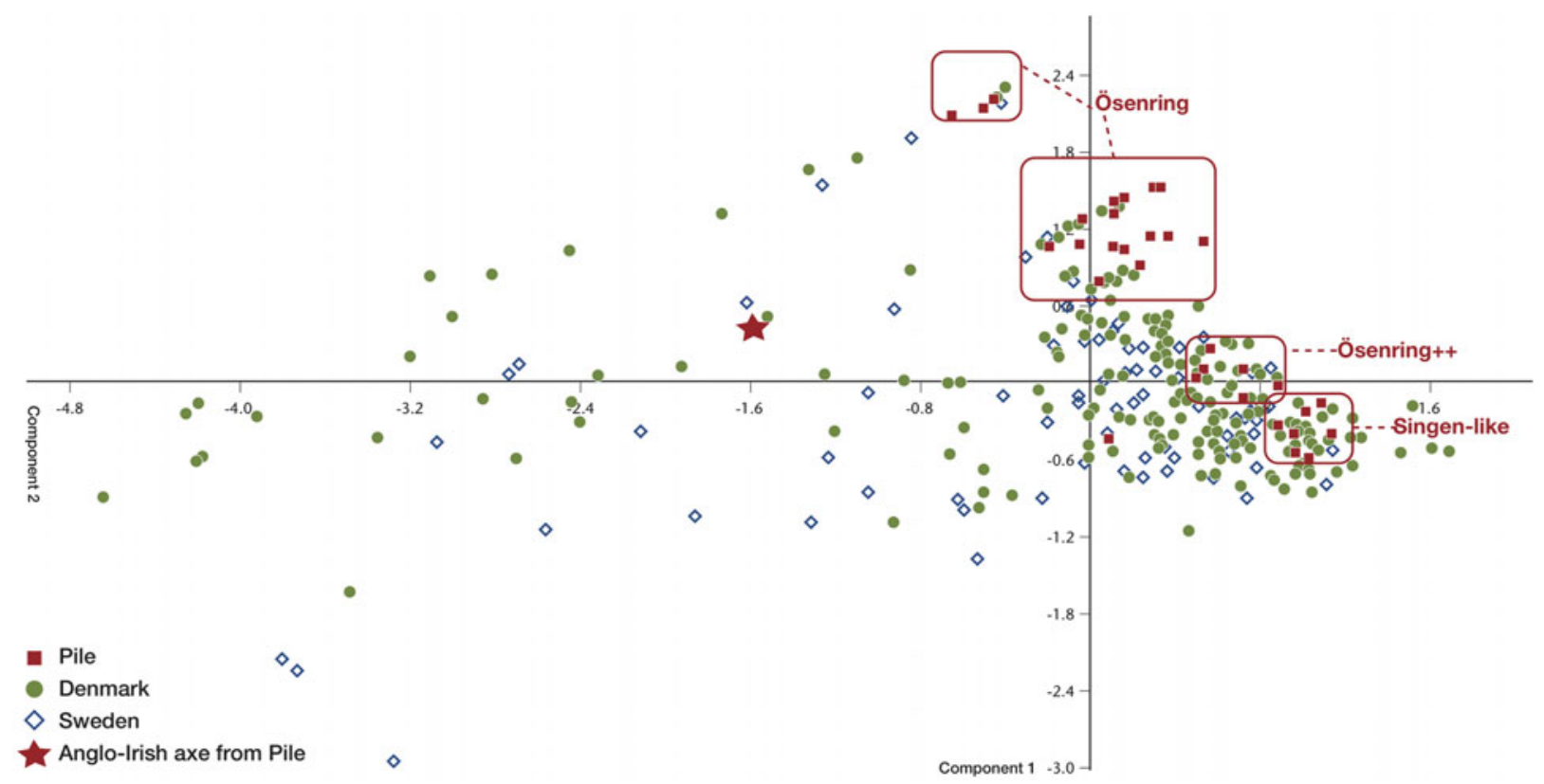

Fig. 8 .

PCA plot. Metal compositions at Pile are condensed in their trace elemental components when compared to the wider spread of contemporaneous metal analyses/objects from Denmark and Sweden (318 analyses). This condensed pattern recurs when plotting data for other hoards. This may indicate that the hoards represent a relatively brief period of metalworking before the objects were deposited soon after the metal's arrival. In many cases, the outliers are British axes, which plot very differently than the predominant fahlore copper used (after Vandkilde 2017a, 138, fig. 81; () Helle Vandkilde)

The local and the regional in south-west Scania: The Pile wetland sacrifice amidst coastal settlements o ancestral monuments

Pile was a seaport where metalworking was carried out around 2000 BC (Fig. 9). In all likelihood, it was a landing place where metals and exotic objects arrived routinely as the result of frequent transfers. In particular, travels crossed the Baltic Sea to the metal-rich Únětice area, but clearly, Pile was connected to other places, both near and far. It is conceivable that Pile was also a ritual hotspot. A gallery grave and a dolmen originally stood tall on the seaside promontory of Sjötorp, probably visible when arriving from the sea, as well as from the wetland site of ritual deposition. Various sources suggest that the hoard was deposited in a water lock, surrounded by six settlements on higher ground (Vandkilde 2017a, 13-40). This suggests a high population density at Pile, consistent with what is otherwise known about this period in terms of marked settlement expansion (eg, Mathiassen 1959; Björhem \& Säfvestad 1989; Apel 2001; Björhem \& Magnusson Staff 2006).
Scaling up from local to regional in south-west Scania offers an immediate context for Pile, and a window into the organisation of coastal settlements. The micro-maritory model (Fig. 10) is consistent with the recorded finds and landscape features along the long stretch of coast. Rapid transit to and from Pile and between maritories became possible simply by hugging the coast (cf. Needham 2009). The Scanian coastland was not permanently colonised until c. 2200-2100 BC, in parallel with distinct Late Neolithic expansions elsewhere in Scandinavia. Previously swampy coastlands may have become habitable as they dried out and became fit for agriculture. Two-ailed longhouses occur throughout the open landscape, mainly as single farms, each inhabited by a nuclear or extended family. The village-like cluster of houses at Almhov, $6 \mathrm{~km}$ north of Pile is an exception to this norm (Brink 2013).

To some extent, settlements were specialised, as they depended on one another in a networked economy on the coastal plain. Economic growth is broadly suggested by the cultivation of several crops, 


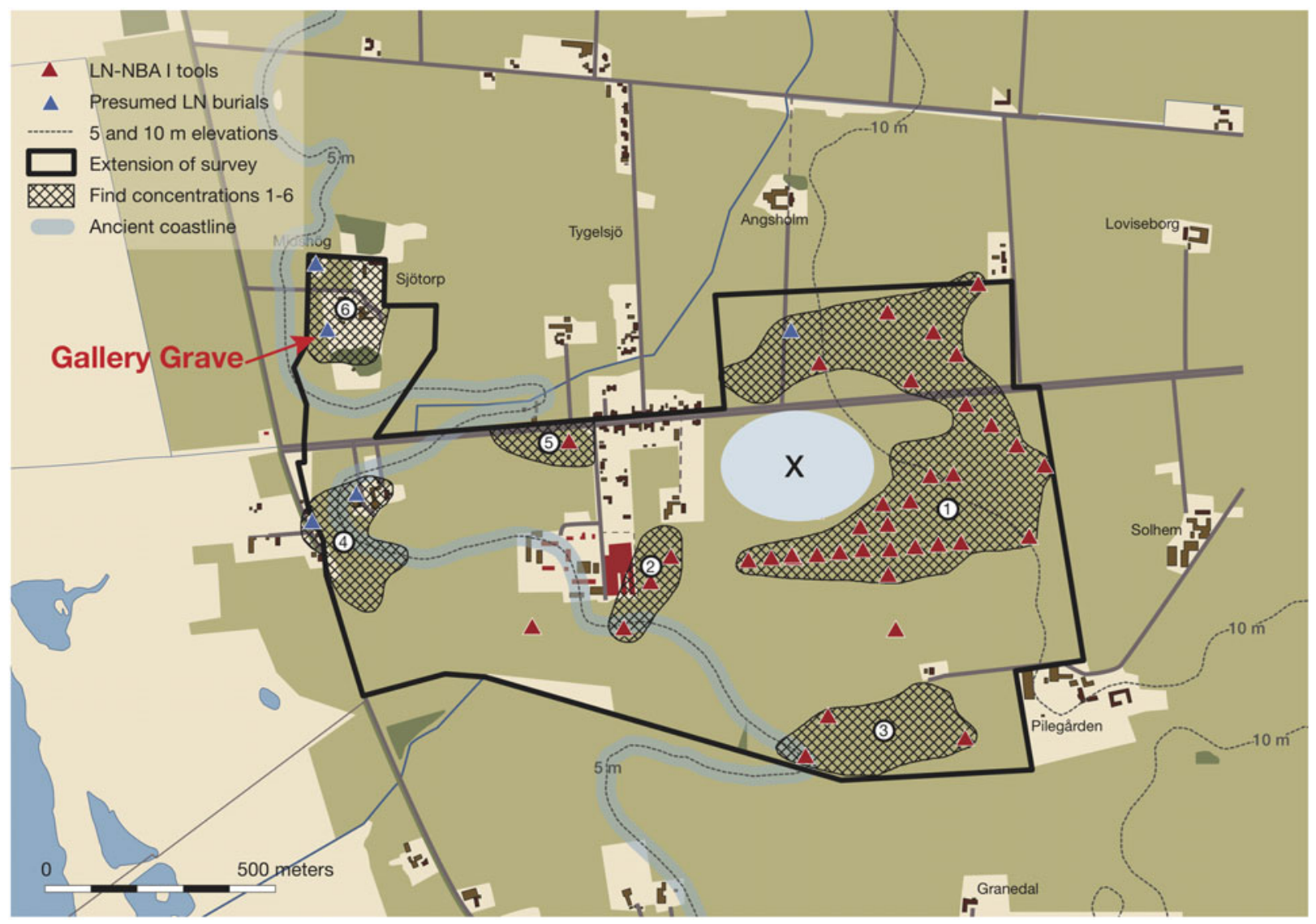

Fig. 9.

Pile is a place in a coastal landscape of shallow bays and small peninsulas. It was then a mosaic landscape, rather flat, with wetlands alternating with drier plateaus, and framed by two rivers and the sea. The wetland site of the hoard is surrounded by higher plateaus where archaeological surveys identify at least six settlements, which may have been coeval with the hoard and the nearby statements in stone (adapted from Vandkilde 2017a, 32, fig. 13A)

several cereals, intensive manuring, and animal husbandry on the extensive grasslands, in addition to fishing and the gathering of wild resources (Brink 2013). Hugging the coast within and between maritories could contribute immensely to such a networked organisation along which everyday goods, high-tech items such as metal axes, people, and ideas could easily travel.

The entrepôt at Pile should be understood in the context of the foregoing type of interconnected local setting, while also contributing through the manufacture and trade of desirable metal axes and news of the world at large. Metal axes contributed actively to daily life. This is clear from the high degree of use wear on over $60 \%$ of the known low-flanged axes (Vandkilde 2017a, 125, fig. 68) (cf. Fig. 10), which testifies to their practical role in the economy, for example, for clearing land. They must have been instrumental in building boats and the longhouses, some of which are impressively large. Overall, there may have been a positive feedback loop of changes in a 'hot' socio-economic atmosphere. Climate change may have been influential, if the 4.2 kiloyear aridification event played a role as a push factor (Meller et al. 2015; Vandkilde 2017a, 51-2).

\section{Emerging Nordic metal-based culture in Southern Scandinavia: networked entrepôts}

Scaling up from Pile to the region of Scania provides further insight into the connectivity and organisation of early metalworking and trading. A number of potential metal entrepôts emerges when mapping the metalwork of the period. Other sites similar to Pile 


\section{H. Vandkilde. BRONZE AGE BEGINNINGS - A SCALAR VIEW}
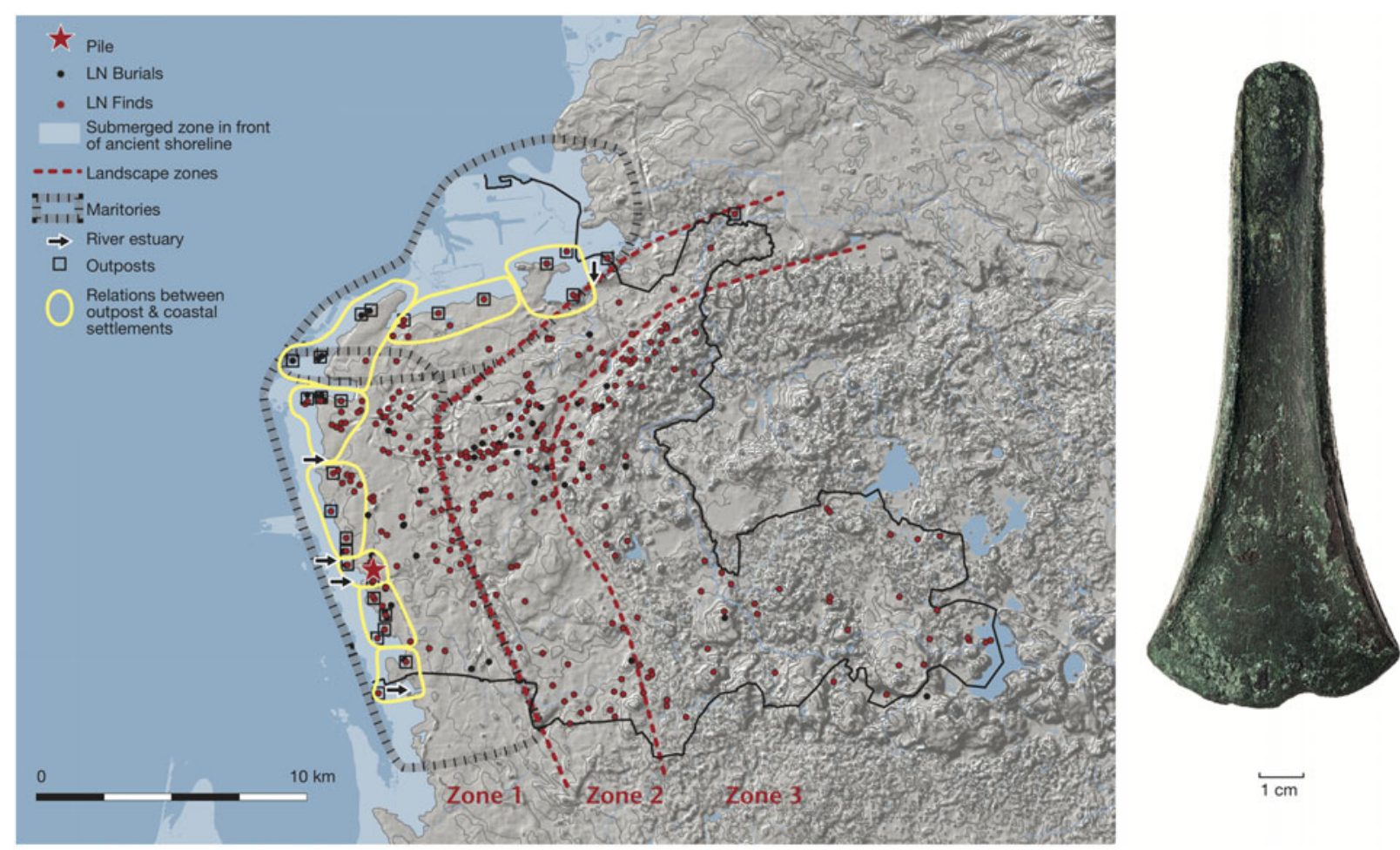

Fig. 10.

Pile in its local context of south-west Scania. The suggested micro-maritory organisation of the three zones of coastal landscape in south-west Scania around 2000 BC. This map strongly indicates the archipelago character of the outer coastland colonised around this time. The longhouse village of Almhov lies a mere $6 \mathrm{~km}$ north of Pile. Effective metal axes may explain the construction of such timber-demanding longhouses (after Vandkilde 2017a, 51, fig. 27, 68, fig. 36B; photo: Ola Myrin, The Swedish History Museum; graphics by Unit of Archaeological IT AU Moesgaard)

exist, even if this site still stands in a category of its own in Scania. Hoards with metalwork identify five other candidates: the multiple hoard at Fjälkinge in the archipelago of north-east Scania, and the string of four axe hoards along the south Scanian coast. More hoards quite possibly existed, now lost. Indeed, a position by the sea, or with easy access to the sea, is common to these sites, which are also placed to avoid perilous waters (Fig. 11).

The wide geographical dispersal of the Pile-type axe is striking, even thrusting into Scania's inner tracts. Therefore, it is possible to classify all six sites, not only as landing places for incoming metal, but also as small-scale metalworking sites, which were nodes in the regional trade that transferred Pile-type axes, and probably other goods, such as flint daggers. The wide geographical spread of the local axe style evinces connectivity along the coast and inland, tying even distant communities to the network. However, in the context of Scania, Pile is exceptional; a smallscale hub with clear parallels only in the rest of Southern Scandinavia and even farther away.

Scaling up to the geography of Southern Scandinavia reveals that Pile had a number of parallels, judging primarily from hoard content and the settings of sacrifices. In parallel with the Scanian situation, maritime connectivity provides a clue to understanding hoards in particular as indicators of ancient entrepôts driven by metalworking or trading (Fig. 12). A few of the sites are as significant as Pile. Pile equivalents are Gallemose and Skeldal in central Jutland, and perhaps Vigerslev in east Sealand (Vandkilde 1990; 1992a; 1992b; 2017a, 114, fig. 62). The maritime routes effectively spread traditional material culture, exotica, and trading goods such as pressure-flaked flint daggers, amber beads, and metals.

When focusing on metal objects, each hoard confirms intersections of the Nordic, British, Northern 


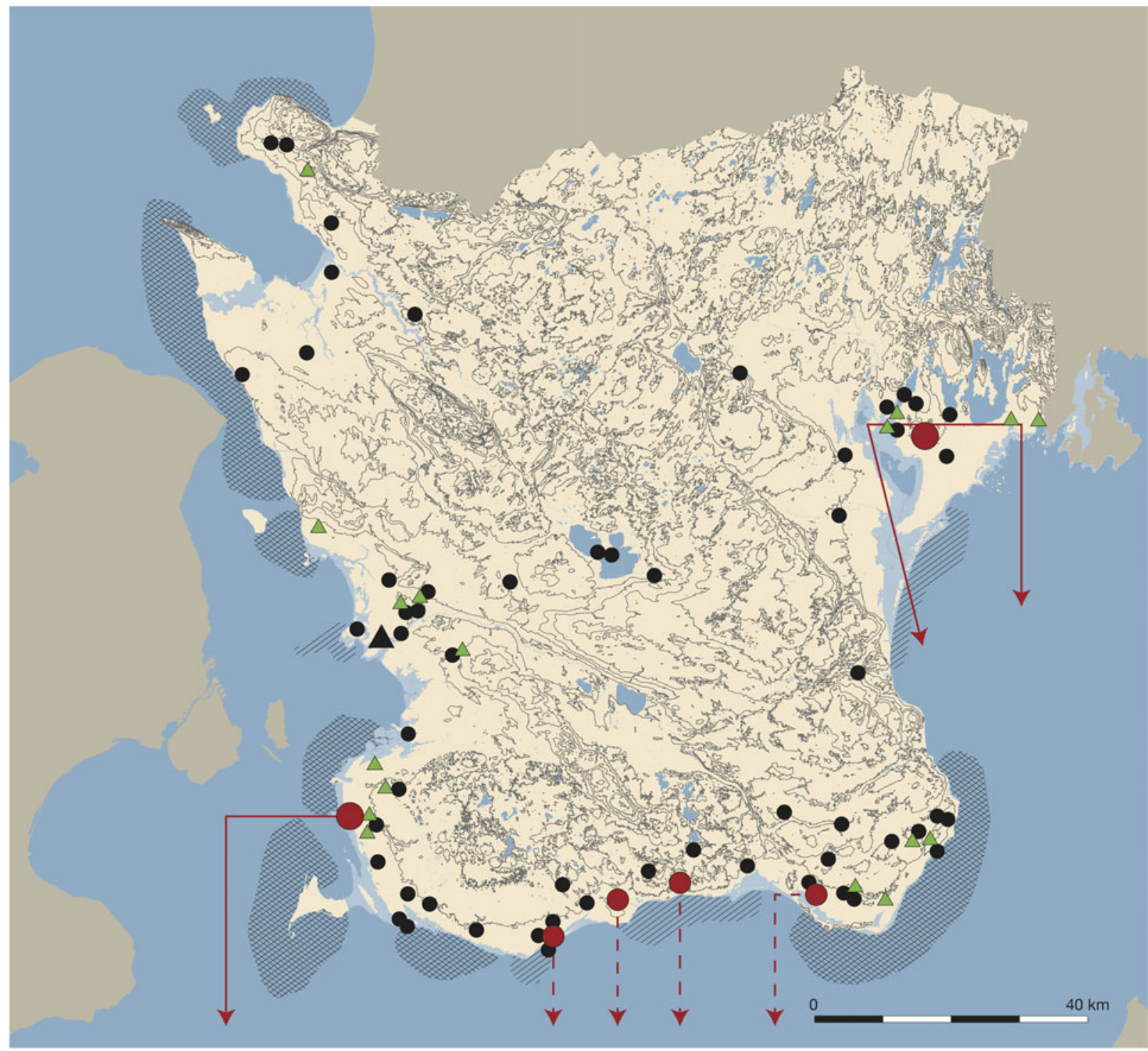

Multi-type hoard

Axe-hoard (min. 2 axes)

Únětician import

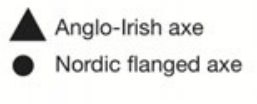

Historical Shipwrecks

Submerged zone in front of ancient shoreline

Relatively common

Numerous

Fig. 11 .

Pile in its regional context of Scania with at least five other hoard sites. Each may deserve to be called a metalworking port, an entrepôt. Their coastal location, associated with relatively calm waters, may indicate that they provided metals from across the Baltic Sea. The connecting routes crossed the Baltic Sea, but also went along the Scanian coast and towards the interior of the region, as the wide distribution of local Pile-type axes and other typical Late Neolithic culture may show (after Vandkilde 2017a, 171, fig. 102; graphics by Unit of Archaeological IT AU Moesgaard)

Únětice and Middle Elbe-Saale Únětician hubs. The Alpine connection is visible only in the continued presence of the nickel-free fahlore copper, ösenring copper (Nørgaard et al. 2019), and this may emphasise once again the Unětician intermediary role of transferring fahlore copper to the north. In these multiple hoards, local and global worlds intersected in a manner that is even more intriguing when scrutinising particular 


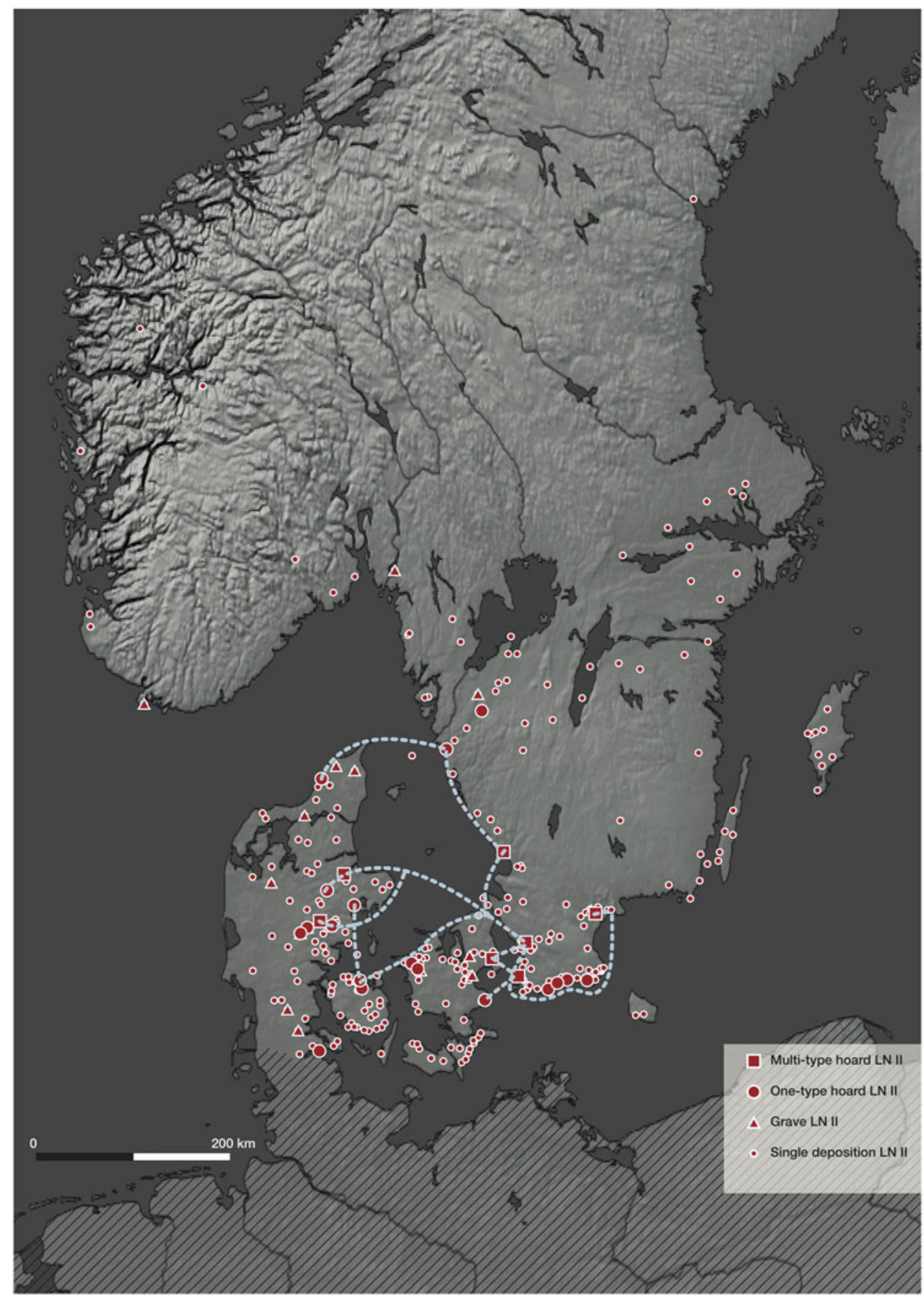

Fig. 12.

Pile in its trans-regional context of Southern Scandinavia. By linking metal-carrying hoards and burials to each other, a wider maritime network emerges; this network was presumably sustained by both Nordic and international connections. This networked trans-region appears to be a cultural zone in its own right, owing to the presence of Late Neolithic culture throughout. The border between Nordic and international is blurry due to ongoing responses to globalisation (after Vandkilde 2017a, 152, fig. 91; graphics by Unit of Archaeological IT AU Moesgaard) 
objects: locally-made axes, Únětician imports, and one British bronze flat axe are accompanied by priceless inalienable objects: the silver ring from Pile, the three large wagon(?) hooks from Gallemose, and the lidded beehive-shaped box containing two gold rings from Skeldal. These metal objects were hoarded in assemblages so amazingly similar in their internal intersecting structure that personal ties must have linked these maritime hubs. In particular, the unique items bring to mind the Kula ceremonial exchange that covered and connected huge Pacific seascapes, in many cases expediting separate commodity trading (Malinowski 1922). More remotely, this may recall the repatriates of contemporary Island Melanesia, who use their strategic combinations of old and new ways when navigating the complexity of local politics and strong traditions.

\section{Global intersections: Únětice as a node with a persistent British link}

Retaining a Scandinavian outlook, and scaling up one level more, the Unertician intersociety stands out as the principal supplier of East Alpine copper (Fig. 3). It would have been easy to travel from Pile to the shores of Mecklenburg as a metal pick-up zone. This trip across the Baltic Sea would have taken roughly the same time as sea voyages internally in Southern Scandinavia, for example from Pile in Scania to Gallemose in east Jutland. Embarking on a still longer journey by sea and river to the Circum-Harz hubs would probably have involved much the same investment of time as travelling by sea to the British Isles (Fig. 6). The geographically wide-spread Únětice koiné emerges as generally important, particularly the hub at Halle-Saale (Fig. 13).

In parallel with Scandinavia, different worlds intersect in the great hoard of Dieskau 2 (cf. von Brunn 1959). This hoard, with its c. 69 metal objects and 106 amber beads, is a key find of the Middle ElbeSaale hubs that were especially concentrated in the Halle-Saale area. Despite its much larger volume, Dieskau 2 has a structure and content that strikingly recall the Scandinavian hoards: Pile, Gallemose, and Skeldal, in particular. Like these, Dieskau includes several local flanged axes (Únětice-type) and similarly incorporates other worlds, namely the Nordic area (amber necklaces), the British area (developed bronze flat axe with rain pattern), and the Eastern Alpine-Danubian region (several ösenhalsrings) (see
Vandkilde 2017a, 148, fig. 88). This may underpin the idea posited above, concerning the involvement of personal relations: a group of cosmopolitans emulated each other while agreeing on a ceremonial format, with axes being by far the most abundant element of each deposition, followed by rings and spiced with rarer items. Considering the East Alpine provenance of the Pile copper, and the continued importance of the ösenring copper in Southern Scandinavia 2000-1700 BC, the Alpine-Danubian intersection in the Dieskau hoard, and in other Unětician hoards, is surely significant. This may further sustain the idea of the Unětice area as the intermediary trading partner of Alpine fahlore copper to the North, particularly involving the CircumHarz hubs.

Culturally, the British Isles appear more foreign to Scandinavia than does Únětician central Europe, with which ties seem much closer. The British connection rests on Baltic amber exchanged for the attractive, tin-rich bronze flat axes. Outside of Britain, Scandinavia has the largest number of such British axes (Fig. 14). Mapping these resources elucidates the triangular linkage of Southern Scandinavia, the British Isles and the Únětician hubs. Amber was a key commodity. First, amber concentrates in the Unětician hubs coinciding with a number of British axes. Second, Wessex, rich in burial mounds of the Bush Barrow variety, is another amber-rich hub. This may have involved exchanges of prestige goods or similar ceremonial forms of transactions. Copper and tin for metalworking on the return to Scandinavia are other reasons for making these long-distance journeys. In this sense, the British axes may be understood as a kind of tin ingot. Recent research has identified a proportion of British copper in the earliest Scandinavian metalwork, suggesting that the exotic British axes were eventually recycled into locally-made Pile style axes (Nørgaard et al. 2019). Scandinavian travellers probably hugged the coast to the Rhine Estuary and crossed the Channel to the Thames estuary (Isle of Thanet) (cf. Fig. 14).

\section{Scaling down to south-west Scania: keeping the global in check}

The question remains: how did this first wave of bronzisation impact traditional societies in the north? High mobility is apparent in a hot atmosphere of thriving economy, population expansion, and 


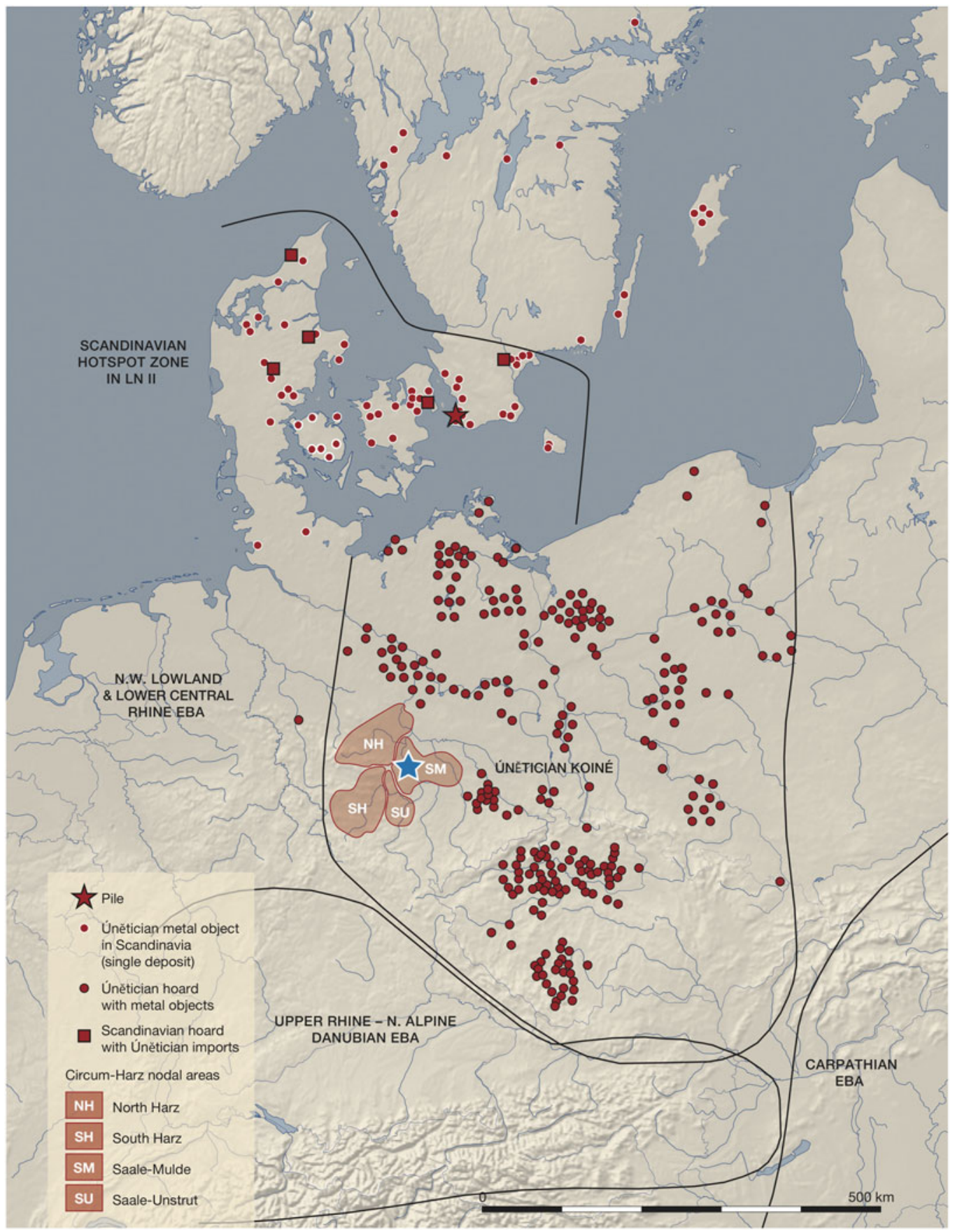

Fig. 13.

Southern Scandinavia and continental Europe, with the dominant presence of the Únětician koiné, of which the Circum-Harz group of hubs of the Middle Elbe-Saale stands out. The Mecklenburgian coastal zone provided an opportunity to routinely to pick up new metal supplies. Here, I argue that the Únětice region generally functioned as the intermediary of fahlore copper to Southern Scandinavia, where metalworking was limited to Scania and the Danish Isles at this early date (after Vandkilde 2017a, 147, fig. 87; graphics by Unit of Archaeological IT AU Moesgaard) 


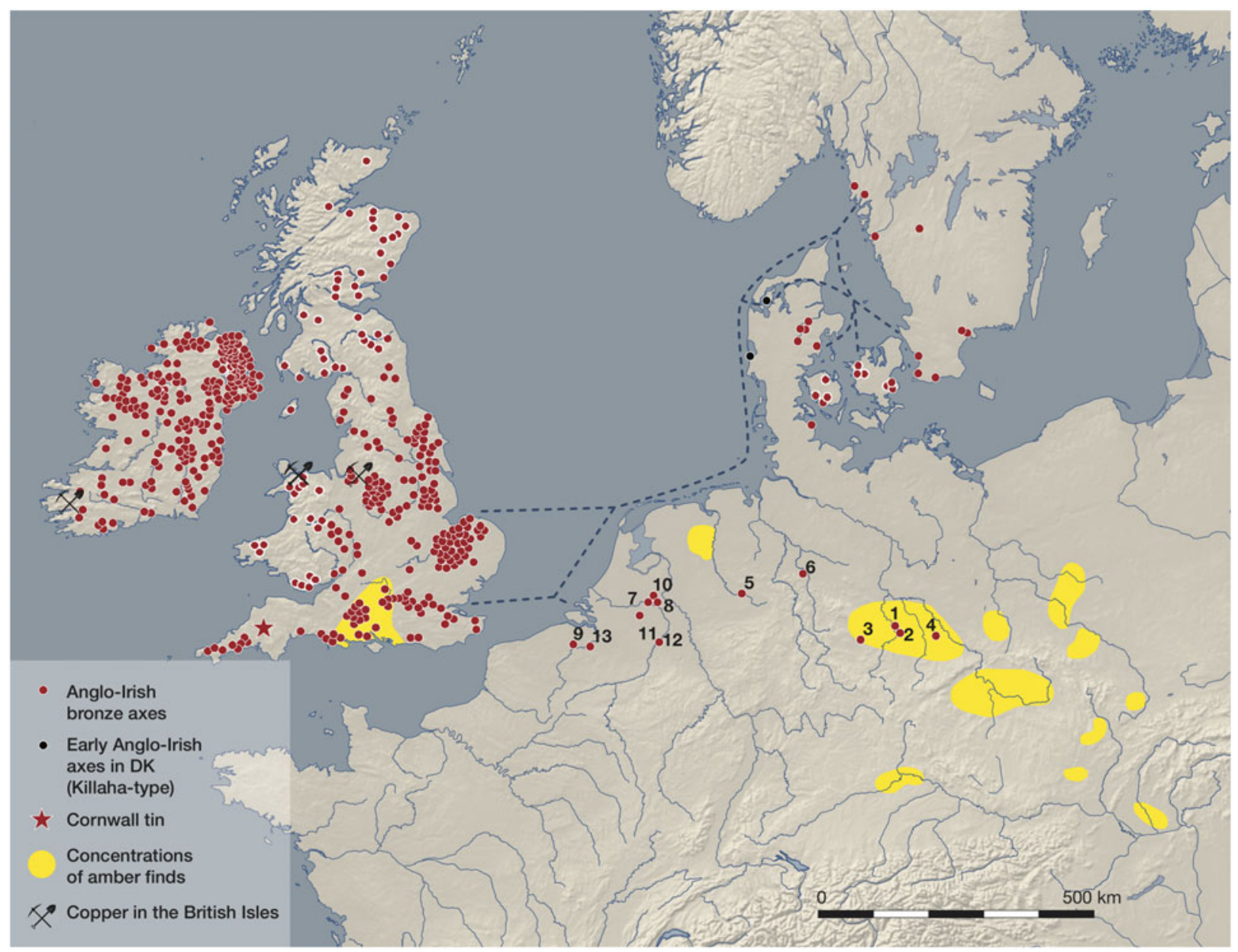

Fig. 14.

The triangular interrelationship of S. Scandinavia, British Isles, and Únětician Circum-Harz hubs is attested by the distribution of British bronze flat axes and Baltic amber. Amber is naturally available in S. Scandinavia also boasting the largest number of British axes outside the British Isles. The find cluster of amber in Wiltshire springs to the eye. The rich Wessex mound burials of this period often include amber necklaces. Three miniatures of metal-hilted halberds confirm the Wessex-Únětician link (cf. Needham 2009; 2017). The Circum-Harz hubs appear as another cross-road involved in the exchange of amber, as well as British axes (after Vandkilde 2017a, 142, fig. 85; graphics by Unit of Archaeological IT AU Moesgaard)

technological innovations. All this is characteristic of globalisation phases, although in this case, climate change may have contributed to the general situation of growth. Exogenous impact is evident to varying degrees in the adoption of metallurgy, in local metalwork, timber-demanding two-aisled longhouses, pressure-flaked flint items and more generally, burial customs and the construction of great gallery graves, the pottery styles, and dress accessories, such as bone pins that copied metal versions from EBA central Europe. On the one hand, much of this may be understood in terms of a robust tradition, which was, however, not stationary. It spread and consolidated as a common Nordic tradition that established bonds between people at local, regional, and trans-regional levels. On the other hand, in many cases Nordic culture may be traced to foreign forms. In other words, the border between the local and the global is rather blurry, which is also typical of ongoing globalisation.

The metals of copper and bronze, more rarely of gold and silver, are doubtless the clearest case of transcultural substances that disrupted boundaries and undermined local autonomies in and outside 
Southern Scandinavia. At the same time, it is unlikely that the early metal was distributed without constraints in local-level exchanges within the well-ordered and networked communality that inhabited the coastal zone, as shown by Brink (2013) for south-west Scania. Drawing on the Melanesian analogy, the metal, an externally derived resource, may not have been subject to normal rules of reciprocation. The accumulation of exquisite items at Pile may tell as much. This may mean that new forms of social distinction were developing, which would accord with the Melanesian analogy.

In south-west Scania, in the vicinity of the Pile seaport, numerous longhouses were built on the coastal plain in the same period. Some farms were fenced, as seen at Dösemarken in the Hyllie Bog community near the village of Almhov, which comprised a number of farms that no doubt participated on fairly equal terms in a subsistence economy. Nevertheless, house sizes differ markedly at Almhov, and generally on the plain. The similar architectural canon and the networked economy emphasise a strong communal embedment, whereas dissimilar house sizes may illustrate the countertrend of emerging social inequality (Brink 2013). Similar trends may be tracked throughout Southern Scandinavia around this time (eg, Winther Johannsen 2017; Borup 2018). The favoured metal axes were instrumental in building the timber-consuming houses, and to preparing the fields, felling trees, and notably, also in expediting social distinctions, owing to the clear difference between those possessing metal and those lacking this status material. In this perspective, metal provided a comparative advantage for certain entrepreneurial individuals who possessed diverse skills at sea and at home; all this took place in, and contributed to, a hot socio-economic climate.

The strategy of reinventing tradition transpired through the material culture of the period in question c. 2100-1700 BC. Multi-burial gallery graves were erected at the edge of the sea along the Scanian coasts as visible markers of communality and rooted tradition, as they effectively renewed an ancestral megalithic funerary practice (Vandkilde 2017a, 50, fig. 26). In many cases, megalithic passage graves and dolmens were reused as burial spaces. This strategic renewal of ancestral statements in stone is paralleled in the wetland hoarding of valuables, which may have had similar connotations of pleasing the ancestors and maintaining social coherence when this was challenged (eg, Karsten 1994). Metal objects were at times sacrificed in wetlands, mostly as single depositions, and sometimes in an assemblage, which is essentially an engrained tradition demanded by prescribed ritual norms. Likewise, the old tradition of producing flint daggers took a clear turn away from the lancet-shaped flint daggers of Bell Beaker derivation. In the Pile period, these pressure-flaked flint daggers were innovated through a creative skeumorphic dialogue with metal-hilted daggers, such as those prominently present in the Pile hoard (cf. Vandkilde 2014b). As indicated by flint-working debris and preforms found on the plateaus surrounding the find place of the hoard, flint daggers and other weapon-tools were probably produced at the Pile site, along with metalwork.

The Melanesian analogy of repatriates evokes the idea that cosmopolitan local entrepreneurs instigated the strategies of tradition renewal. The double purpose may have been to calm local anxieties about an open and changing world, and to gain followers in the quest for leadership. Whether this increased friction or soothed it, we cannot know, but the social divisions are subtle, and there are no signs of social revolution. The biggest longhouses were surely oversize (up to $50 \mathrm{~m}$ long), but they were erected according to the tradition for two-aisled longhouses, traceable back to the first Corded Ware in Scandinavia (Simonsen 2017). The big-house case is directly comparable to the Melanesian analogy, above.

The still-vaguely-expressed social inequality (beyond that of age and gender) in the material culture (eg, settlements, burials, personal equipment, and accessories) may be argued to correlate with the relatively small amounts of metal in circulation around 2000 BC (Fig. 15). This first threshold reflects the onset of bronzisation in many regions with expanding economies, and the increasing integration of metals, although it still involved fairly restricted recycling and mixing of copper of various origins. The Nordic sphere of interaction expanded during this process, intersecting the British Isles to the west and the Únětician intersociety to the south. There is no evidence of these spheres of interaction being transgressed. This situation changed considerably around $1600 \mathrm{BC}$, with the breakthrough of the Nordic Bronze Age. To the south, the breakdown of what we call the Únětice culture brought Scandinavians in direct contact with the tell cultures of the Carpathian Basin, and, perhaps less directly, the steppe zone and the Aegean palatial polities, which were also expanding (Fig. 3) (Vandkilde 2014a). 


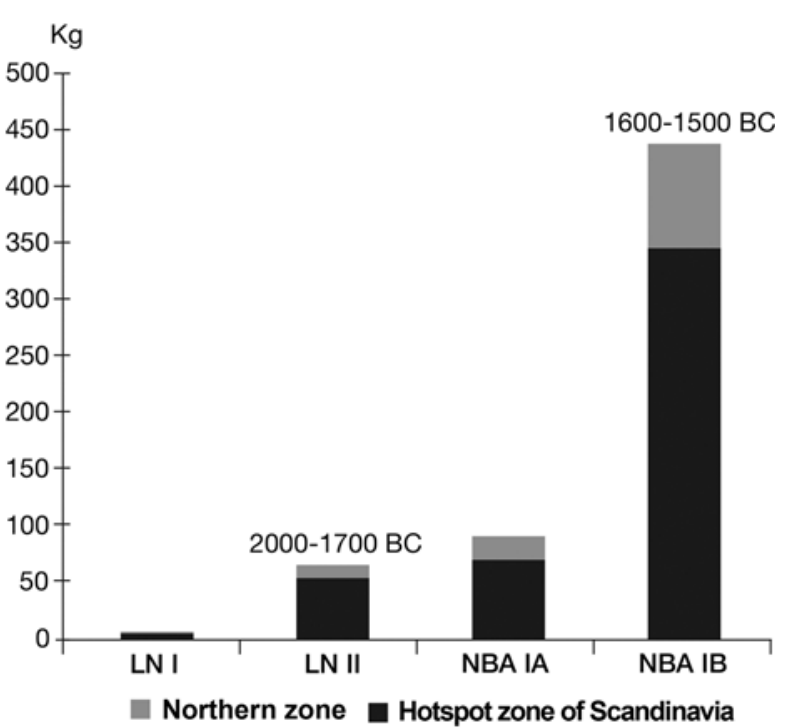

Fig. 15 .

Based on metal weight per hundred year, this histogram demonstrates the increase in metal consumption c. 24001500 BC. Southern Scandinavia emerges as the metallurgical hotspot of Scandinavia during the entire period. The time of Pile marks the first distinct increase in the availability of metal due to the metallurgical consolidation that took place. This correlates broadly with the initial phase of bronzisation in the Bronze Age hyper-region (cf. Fig. 1). In 1600 BC, a much more distinct benchmark emerged, that being the development of the NBA as a cultural zone in its own right. The $1600 \mathrm{BC}$ threshold corresponds to the beginning of an expansion seen globally throughout the hyper-region, giving rise to mining activities of industrial proportions (after Vandkilde 2017a, 153, fig. 93; (C) Helle Vandkilde)

The 1600 BC watershed: Nordic cultural change and expanding spheres of interaction

When the long-drawn transformation to the NBA approached completion, c. 1600-1500 BC, this was partly explainable with reference to the considerable amounts of metal now in circulation (Fig. 15). Some longhouses grew to $60 \mathrm{~m}$ long (Artursson 2009, 95, fig. 26); large labour-intensive burial mounds were built for particular persons and lineages (Holst \& Rasmussen 2015); new forms of elitist warriorhood, coupled to a new cosmology, were developing with amazing cultural creativity across the board (Vandkilde 2014a). A class of unfree may also have developed through growing commodification of unfree human subjects (Ling et al. 2018). By 1500 $\mathrm{BC}$, culture and economy flourished throughout Southern Scandinavia, and bronze was becoming more common and therefore more difficult to monopolise. Responses to transcultural flows still existed, including a vibrant Nordic culture that produced and used metalwork. It is difficult to assign an exact social label to these Scandinavian developments at the threshold of the NBA proper, beyond the generalisation of a new, or reformed, social class that consolidated itself. The shadowy 17 th century BC presents difficulties, and a new focus, perhaps on influential demographic changes, might provide new insights (cf. Müller \& Diachenko 2019, fig. 2).

Nordic Bronze Age developments coincided with a marked growth in copper production in many mining areas. For example, the Mitterberg mines in Austria reached industrial proportions. The production targeted rib ingots, tons of which were manufactured from a new copper type (Radivojević et al. 2018). This is a medium-low impurity copper, characteristically low in silver. This uniform chalcopyrite copper started to arrive in Scandinavia in the 17th century BC. By 1600 BC, this copper, perhaps from Mitterberg, was completely prevalent in the metalwork production in Scandinavia and elsewhere (Nørgaard et al. 2019). This may illustrate a globalisation entirely led by the production, trade, and consumption of bronze: at this point, this alloy, with a tin percentage between 8 and 10\%, was standard.

\section{Pile and elsewhere: summing up}

As outlined above, the Pile site plays a key role in an effort to trace Bronze Age beginnings. Pile was both an agent and a result of bronzisation, one of the numerous sites in Afro-Eurasia around the time of Bronze Age beginnings, c. 2000 BC. Pile drew on the local and the foreign, as shown by its blend of objects, the metal, and its coastal setting, with maritime access to coveted metals. Pile lies at the outskirts of the Bronze Age world, but despite this location, there are clear signs of bronzisation with multi-scalar connectivity from the local to, in principle, the hyper-region of Afro-Eurasia. This increased access to the world is observed from the Scandinavian perspective, which first engaged with the British Isles and Únětice as melting pots, and later with the Carpathian Basin. Metal and metal-related culture provided a comparative advantage when navigating the local competition for influence and leadership. Generally, the global was strategically translated into local tradition, with the reinvention of tradition as one strategy. Social friction generated slow change, rather than social revolution. 


\section{H. Vandkilde. BRONZE AGE BEGINNINGS - A SCALAR VIEW}

The real tipping point in terms of a societal transformation came in 1600-1500 BC, when the NBA emerged within a considerably enlarged world. Large amounts of metal were by now in circulation. The $1600 \mathrm{BC}$ watershed marks an expansion of interconnectivity, from medium to very large: the NBA took off $1600-1500 \mathrm{BC}$ through internal social development coupled to long-distance connections. Seen from the non-urban north, a considerably increased access to the world brought new opportunities. The mutuality of the process must be emphasised. The Carpathian Basin rose as a cultural crucible enriched by resources from the Pontic steppes, the Aegean, and also quantities of amber from the North. Interest still centred on amber and metals, but also warrior culture: swords, chariots, horses, and a novel tripartite cosmology (Vandkilde 2014a; Kveiborg 2018). All this arrived in Scandinavia, fuelling a presumably ongoing cultural and social change.

\section{COMPARING GLOBALISATION: CONCLUSION}

As a concluding reflection, it is pertinent to ask whether present-day globalisation is unique. The answer is yes, in terms of its global reach and complexly scalar reality. The answer is no, if we consider how, in the deep past, scalar macro-regimes were bound together by key resources - notably, bronze in the Bronze Age. It is also no, if we consider periods of prehistory during which exogenous factors drove societal magnitude and change. This article's claim is that the Bronze Age was a unique kind of pre-modern globalisation.

Can we learn from prehistoric globalisation? Perhaps we can. It is particularly important to note that globalisation has a history and that disruption seems more intrinsic to global eras than to eras with a more fragmented, regionalised general structure. It should also be emphasised that the Bronze Age version of globalisation expedited innovation. Can globalisation end? The Bronze Age ended, and a much more fragmented world of many autonomous units emerged: the Iron Age.

Acknowledgments. I am grateful to the Prehistoric Society for this unique opportunity to present my research and thoughts about the Bronze Age. It is a privilege to earn the Europa Prize and much more than I have hoped for. Thanks to all the research partners with whom I have collaborated with over the years. Thanks also to the speakers at the conference hosted by the University of Southampton, my students, and my family for all their support and patience. Finally, I would like to express my appreciation to all of you, who have just listened to my ideas about the exciting Bronze Age.

\section{BIBLIOGRAPHY}

Anthony, D.W. 2007. The Horse, the Wheel, and Language: How Bronze-Age riders from the Eurasian Steppes shaped the modern world. Princeton, NJ: Princeton University Press

Appadurai, A. 2010. How histories make geographies: Circulation and context in a global perspective. Transcultural Studies 2010(1), 4-13

Apel, J. 2001. Daggers of Knowledge \& Power: The social aspects of flint-dagger technology in Scandinavia 2350-1500 cal. BC. Uppsala: Coast to Coast Book 3

Artursson, M. 2009. Bebyggelse och Sambällsstruktur: Södra och Mellersta Skandinavien Under Senneolitikum och Bronsålder 2300-500 f. Kr. Stockholm: Riksantikvarieämbetet

Bevan, A. 2010. Making and marking relationships: Bronze Age brandings and Mediterranean commodities. In A. Bevan \& D. Wengrow (eds), Cultures of Commodity Branding, 35-85. Walnut Creek, CA: Left Coast Press

Bintliff, J. (ed.) 1991. The Annales School and Archaeology. Leicester: Leicester University Press

Björhem, N. \& Säfvestad, U. 1989. Fosie IV. Byggnadstradition och bosätningsmönster under senneolitikum. Malmöfynd 5. Malmö: Malmö Museer

Björhem, N. \& Magnusson Staaf, B. 2006: Långhuslandskapet. En studie av bebyggelse och sambälle från stenålder till järnålder. Malmöfynd 8 . Malmö: Malmö Kulturmiljö

Brink, K. 2013. Houses and hierarchies: Economic and social relations in the Late Neolithic and Early Bronze Age of southernmost Scandinavia. European Journal of Archaeology 16(3), 433-58

Broodbank, C. 2013. The Making of the Middle Sea: A history of the Mediterranean from the beginning to the emergence of the Classical world. Oxford: Oxford University Press

von Brunn, W.A. 1959. Die Hortfunde der frühen Bronzezeit aus Sachsen-Anhalt, Sachsen und Thüringen. Schriften der Sektion für Vor- und Frühgeschichte/ Deutsche Akademie der Wissenschaften zu Berlin Band 7(1). Berlin: Akademie-Verlag

Borup, P. 2018. Østbirk - a strategic settlement at the end of the Neolithic. Journal of Neolithic Archaeology 20, $83-130$

Cline, E.H. 2014. 1177 BC: The year civilization collapsed. Princeton, NJ: Princeton University Press

Cunliffe, B. 2015. By Steppe, Desert, and Ocean: The birth of Eurasia. Oxford: Oxford University Press

Czebreszuk, J. 2007. Amber between the Baltic and the Aegean in the third and second millennia BC (an outline 
of major issues). In I. Galanaki, H. Tomas, Y. Galanakis \& R. Lafineur (eds), Between the Aegean and Baltic Seas: Prehistory across borders. Proceedings of the International Conference, Bronze and Early Iron Age Interconnections and Contemporary Developments between the Aegean and the Regions of the Balkan Peninsula, Central and Northern Europe. University of Zagreb, 11-14 April 2005, 363-9. Liege: Université de Liége

Earle, T. 2002. Bronze Age Economics: The beginnings of political economies. Boulder, CO: Westview Press

Franchetti, M.D. 2008. Pastoralist Landscapes and Social Interaction in Bronze Age Eurasia. Berkeley, CA: University of California Press

Friedman, J. 1994. Cultural Identity and Global Process. London: Sage Books

Friedman, J. 2006. Culture and global systems. Theory, Culture \& Society 23(2-3), 404-6

Haak, W. et al. 2015. Massive migration from the steppe is a source for Indo-European languages in Europe. Nature 522, 207-11

Hawkes, C. 1954. Archeological theory and method: Some suggestions from the Old World. American Anthropologist 56(2), 155-68

Hobsbawm, E. \& Ranger, T. (eds). 1983. The Invention of Tradition. Cambridge: Cambridge University Press

Holst, M.K. \& Rasmussen, M. (eds). 2015. Skelhøj and the Bronze Age Barrows of Southern Scandinavia. Vol 2. Barrow Building and Barrow Assemblies. Hoejbjerg: Jutland Archaeological Society

Inda, J. \& Rosaldo, R. 2008. Tracking global flows. In J.X. Inda \& R. Rosaldo (eds), The Anthropology of Globalization, 3-46. Oxford: Blackwell Publishing

Jennings, J. 2011. Globalizations of the Ancient World. Cambridge: Cambridge University Press

Karsten, P. 1994. Att kasta yxan i Sjöen. En studie över rituell tradition och forändring utifrän skånska neolitiska offerfynd. Acta Archaeologica Lundensia Series altera in $8^{\circ}$ 23. Stockholm: Almqvist \& Wiksell.

Kaul, F. 2013. The Nordic razor and Mycenaean lifestyle. Antiquity 87, 461-72

Kohl, P. 2011. World-systems and modelling macrohistorical processes in later prehistory: An examination of old and a search for new perspectives. In T.C. Wilkinson, S. Sherratt \& J. Bennet (eds), Interweaving Worlds: Systemic interactions in Eurasia, 7th to 1st millennia BC, 77-86. Oxford: Oxbow Books

Krause, R. 2003. Studien zur kupfer-und frübbronzezeitlichen Metallurgie zwischen Karpatenbecken und Ostsee. Vorgeschichtliche Forschungen Band 24. Rahden/Westfalen: Marie Leidorf

Krause, R. \& Pernicka, E. 1998. The function of ingot torques and their relation with Early Bronze Age copper trade. In C. Mordant, M. Pernot \& V. Rychner (eds), L'atelier du bronzier en Europe du XXe au VIIIe siècle avant notre ère. Actes du colloque international Bronze' 96, Neuchatel et Dijon 1996. Tome II, 219-26. Paris: CTHS

Kristiansen, K. 1998. Europe Before History. Cambridge: Cambridge University Press
Kristiansen, K. \& Larsson, T.B. 2005. The Rise of Bronze Age Society: Travels, transmission and transformations. Cambridge: Cambridge University Press

Kristiansen, K. \& Suchowska-Ducke, P. 2015. Connected histories: The dynamics of Bronze Age interaction and trade 1500-1100 BC. Proceedings of the Prehistoric Society 81, 361-92

Kveiborg, J. 2018. Traversing sky and earth: The Nordic Bronze Age horse in a long-term perspective. Praehistorische Zeitschrift 93(2), 225-64

Linduff, K.M., Sun Y., Cao, W. \& Liu, Y. (eds). 2018. Ancient China and its Eurasian Neighbors: Artifacts, identity and death in the frontier 3000-700 BCE. Cambridge: Cambridge University Press

Ling, J. 2008. Elevated Rock Art: Towards a maritime understanding of Bronze Age rock art in Northern Bohuslan, Sweden. GOTARC Serie B, Gothenburg Archaeological Thesis 49. Gothenburg: Department of Archaeology and Ancient History, University of Gothenburg

Ling, J., Stos-Gale, Z., Grandin, L., Billstrom, K., HjärthnerHoldar, E. \& Persson, P.O. 2015. Representations of oxhide ingots in Scandinavian rock art: The sketchbook of a Bronze Age traveller? Antiquity 89, 191-209

Ling, J., Stos-Gale, Z., Grandin, L., Billstrom, K., HjärthnerHoldar, E. \& Persson, P.O. 2014. Moving metals II: Provenancing Scandinavian Bronze Age artefacts by lead isotope and elemental analyses. Journal of Archaeological Science 41, 106-32

Ling, J., Earle T. \& Kristiansen, K. 2018. Maritime Mode of Production: Raiding and trading in seafaring chiefdoms. Current Anthropology 59(5), 488-524

Malinowski, B. 1922. Argonauts of the Western Pacific. New York, NY: E.P. Dutton \& Co

Maran, J. 2013. Bright as the sun: The appropriation of amber objects in Mycenaean Greece. In H.P. Hahn \& H. Weiss (eds), Mobility, Meaning and the Transformation of Things, 147-69. Oxford: Oxbow Books

Mathiassen, T. 1959. Nordvestsjoellands Oldtidsbebyggelse. Nationalmuseets Skrifter. Arkæologisk-historisk Række VII. København: Nationalmuseet

Mead, M. 1930. Melanesian Middlemen: A description of the trading people of the Admiralty Islands who have built up an elaborate system of primitive markets and who make long overseas trading voyages in their slender out-rigger canoes. Natural History 30(2), 115-30

Mead, M. 1956(1975). New Lives for Old: Cultural transformation - Manus, 1928-1953. New York: William Morrow \& Co

Meller, H., Arz, H.W., Jung, R. \& Risch, R. (eds). 2015. 2200 BC - Ein Klimasturz als Ursache für den Zerfall der Alten Welt?/2200 BC - A climatic breakdown as a cause for the collapse of the old world? 7. Mitteldeutscher Archäologentag vom 17. bis 19. Oktober 2013 in Halle (Saale). Tagungen des Landesmuseums für Vorgeschichte Halle 12. Band I-II. Halle/Saale: Landesmuseum für Vorgeschichte

Montelius, O. 1880. Ett fynd från vår bronsålders äldsta tid. Kongl. Vitterhets Historie och Antiquitets Akademiens Månadsblad 105-108, 129-58 


\section{H. Vandkilde. BRONZE AGE BEGINNINGS - A SCALAR VIEW}

Müller, J. \& Diachenko, A. 2019. Tracing long-term demographic changes: The issue of spatial scales. PLoS ONE 14(1): e0208739

Needham, S. 2009. Encompassing the sea: 'Maritories' and Bronze Age maritime interactions. In P. Clark (ed.), Bronze Age Connections: Cultural contact in prehistoric Europe, 12-37. Oxford: Oxbow Books

Needham, S. 2017. The Classification of Chalcolithic and Early Bronze Age Copper and Bronze Axe-heads from Southern Britain. Oxford: Archaeopress

Needham, S. \& Giardino, C. 2008. From Sicily to Salcombe: A Mediterranean Bronze Age object from British coastal waters. Antiquity 82, 60-72

Nørgaard, H.W., Pernicka, E. \& Vandkilde, H. 2019. On the trail of Scandinavia's early metallurgy - Provenance, transfer and mixing. PLOS ONE. doi: 10.1371/journal. pone. 0219574

Olausson, D. 2013. The flintknapper and the bronzesmith. In S. Bergerbrant \& S. Sabatini (eds), Counterpoint: Essays in Archaeology and Heritage Studies in Honour of Kristian Kristiansen, 449-56. Oxford: British Archaeological Report S2508

Otto, T. 2006. Warfare and exchange in a Melanesian society before colonial pacification: The case of Manus, Papua New Guinea. In T. Otto, H. Thrane \& H. Vandkilde (eds), Warfare and Society: Archaeological and social anthropological perspectives, 187-99. Aarhus: Aarhus University Press

Otto, T. \& Pedersen, P. 2005. Disentangling traditions: Culture, agency and power. In T. Otto \& P. Pedersen (eds), Tradition and Agency: Tracing cultural continuity and invention, 11-49. Aarhus: Aarhus University Press

Radivojević, M., Roberts, B.W., Pernicka E., Stos-Gale Z., Martinón-Torres, M., Rehren, Th., Bray, P., Brandherm, D., Ling, J., Mei, J., Vandkilde, H., Kristiansen, K., Shennan, S.J. \& Broodbank, C. 2018. The provenance, use and circulation of metals in the European Bronze Age: The state of debate. Journal of Archaeological Research, 1-55

Rassmann, K. 2010. Die frühbronzezeitlichen Stabdolche Ostmitteleuropas - Anmerkungen zu Chronologie, Typologie, Technik und Archaometallurgie. In H. Meller \& F. Bertemes (eds), Der Griff nach den Sternen. Wie Europas Eliten zu Macht und Reichtum kamen. Internationales Symposium Halle/Saale 2005, 807-21. Tagungen des Landesmuseums für Vorgeschichte Halle 5. Halle/Saale: Landesmuseum für Vorgeschichte

Ricardo, D. 1817(1811). The Principles of Political Economy and Taxation. New York: Dutton

Robb, J. \& Pauketat, T.R. (eds). 2013. Big Histories, Human Lives: Tackling problems of scale in archaeology. Santa Fe NM: School for Advanced Research Press

Sahlins, M. 2005. The economics of develop-man in the Pacific. In J. Robbins \& H. Wardlow, The Making of Global and Local Modernities in Melanesia: Humiliation, transformation and the nature of culture change, 23-42. Aldershot: Ashgate

Simonsen, J. 2017. Daily Life at the Turn of the Neolithic: A comparative study of longhouses with sunken floors at Resengaard and nine other settlements in the Limfjord region, South Scandinavia. Aarhus: Jutland Archaeological Society/Museum Salling/Aarhus University Press

Skoglund, P. 2009. Beyond chiefs and networks: Corporate strategies in Bronze Age Scandinavia. Journal of Social Archaeology 9(2), 200-19

Spriggs, M. 1997. The Island Melanesians. Oxford: Blackwell Shryock, A. \& Smail, D.L. 2012. Deep History: The architecture of the past and the present. Oakland, CA: University of California Press

Stos-Gale, Z.A. 2017. Interpretation of lead isotope results from the Pile hoard. In H. Vandkilde, The Metal Hoard from Pile in Scania, Sweden: Place, things, time, metals, and worlds around 2000 BCE, 205-12. Aarhus: Swedish History Museum Studies 29

Tsing, A. 2004: Friction: An ethnography of global connection. Princeton, NJ: Princeton University Press

Urry, J. 2007. Mobilities. London: Polity Press

Vandkilde, H. 1990. A Late Neolithic hoard with objects of bronze and gold from Skeldal, central Jutland. Journal of Danish Archaeology 7(1988), 115-35

Vandkilde, H. 1992a. Metal analyses of the Skeldal hoard and aspects of early Danish metal use. Journal of Danish Archaeology 9(1990), 114-32

Vandkilde, H. 1992b. A Late Neolithic hoard from Vigerslev, North Sealand - An archaeological and metal analytical classification. Journal of Danish Archaeology 9(1990), 103-13

Vandkilde, H. 2007. A review of the early Late Neolithic period in Denmark: Practice, identity and connectivity. Offa 61/62(2004/05), 75-109

Vandkilde, H. 2014a. Breakthrough of the Nordic Bronze Age: Transcultural warriorhood and a Carpathian crossroad in the 16th century BCE. European Journal of Archaeology 17(4), 602-33

Vandkilde, H. 2014b. Cultural perspectives on the beginnings of the Nordic Bronze Age. Offa 67/68(2010/11), 51-77

Vandkilde, H. 2016. Bronzization: The Bronze Age as premodern globalization. Prähistorische Zeitschrift 91(1), 103-223

Vandkilde, H. 2017a. The Metal Hoard from Pile in Scania, Sweden: Place, things, time, metals, and worlds around 2000 BCE, 205-12. Aarhus: Swedish History Museum Studies 29

Vandkilde, H. 2017b. Small, medium, large: Globalisation perspectives on the Afro-Eurasian Bronze Age. In T. Hodos (ed.), The Routledge Handbook of Archaeology and Globalization, 509-21. London: Routledge

Vandkilde, H., Hansen, S., Kotsakis, K., Kristiansen, K., Müller, J., Sofaer, J. \& Sørensen, M.L.S. 2015. Cultural mobility in Bronze Age Europe. In P. Suchowska-Ducke, S.S. Reiter \& H. Vandkilde (eds), Forging Identities: The mobility of culture in Bronze Age Europe. Report from a Marie Curie Project 2009-2012 with Concluding Conference at Aarhus University, Moesgaard 2012. Vol. 1, 5-37. Oxford: British Archaeological Report S2771

Wallerstein, E. 1974. The Modern World-System. New York: Academic Press 
Wengrow, D. 2011. 'Archival' and 'sacrificial' economies in Bronze Age Eurasia: An interactionist approach to the hoarding of metals. In T.C. Wilkinson, S. Sherratt \& J. Bennet (eds), Interweaving Worlds: Systemic interactions in Eurasia, 7th to 1st millennia BC, 135-44. Oxford: Oxbow Books

Windybank, S. \& Manning, M. 2003. Papua New Guinea on the brink. Issue Analysis 30, 1-16

Werner, M. \& Zimmermann, B. 2006. Beyond comparison: Histoire Croisee and the challenge of reflexivity. History and Theory 45, 30-50
Wilkinson, T.C. 2014. Tying the Threads of Eurasia: Transregional routes and material flows in Transcaucasia, eastern Anatolia and western Central Asia, c. 3000-1500 BC. Leiden: Sidestone Press

Winther Johannsen, J. 2017. Mansion on the hill - A monumental Late Neolithic house at Vinge, Zealand, Denmark. Journal of Neolithic Archaeology 19, 1-27

Wylie, A. 1985. The reaction against analogy. Advances in Archaeological Method and Theory 8, 63-111

\section{RÉSUMÉ}

Débuts de l'âge du bronze-Vue scalaire des environs globaux, de Helle Vandkilde

Cet article suit les traces de la formation du riche et socialement complexe de lâ ge du bronze nordique (NBA) vers 2000-1500 av. J.-C., en appliquant la méthodologie scalaire et en utilisant l'entrepôt et le site de métalllurgie primitive de Pile en Scanie comme point de départ. En considérant l'âge du bronze comme un exemple ancien de globalisation Islande Mélanésie en périphérie de la globalisation contemporaine est la première examinée pour fournir un équivalent à la culture d'entreprise nordique industrielle et maritime dans laquelle la métallurgie fut adoptée en premier Comment cette marge nordique est-elle devenue l'âge du bronze et quel impact son inclusion a-t-elle eue?. Il est apparu que divers échelons, de local à âge du bronze global se sont croisés dans le trésor de Pile et dans des sites similaires proches et lointains. D’ici env. 2000 av.J-C.les métaux et autres denrées voyageaient le long de réseaux locaux, régionaux et super régionaux bien établis qui incorporaient même les îles britanniques et les centres Úněticiens à la moyenne Elbe-Saale e. De retour en Scandinavie le métal et la culture liée au métal apportèrent un certain avantage quand on naviguait la concurrence locale à la recherche d'influence et de direction. La globalité transculturelle était stratégiquement appropriée localement, utilisant la réinvention de la tradition comme principale stratégie. Le premier boom du métal causa des frictions et un lent changement social plutôt qu'une révolution sociale. Le vrai point de non retour arriva en 1600-1500 av.J.-C. quand le NBA gonflé à bloc émergea à travers un engagement avec un monde considérablement agrandi. A ce moment-là de vastes quantités de métaux étaient en circulation. Vu du nord non urbanisé cette expansion sans précédent de leur monde apporta de nouvelles opportunités mais aussi de profondes tensions sociales. Ainsi les effets de l'adoption de la métallurgie ont infiltré la société et la connexité à tous les niveaux, même en périphérie du monde de l'âge du bronze.

\section{ZUSSAMENFASSUNG}

\section{Bronzezeitliche Anfänge - eine skalare Sicht von den globalen Randbezirken, von Helle Vandkilde}

Dieser Beitrag verfolgt die Bildung der reichen und sozial komplexen Nordischen Bronzezeit (NBA), c. 20001500 BC, indem eine skalare Methodologie angewandt und der Metallverarbeitung aufweisende Umschlagplatz Pile in Schonen als Ausgangspunkt gewählt wird. Die Bronzezeit als historisches Beispiel von Globalisierung auffassend, wird zunächst die Inselwelt Melanesiens an den Rändern der gegenwärtigen Globalisierung untersucht, um eine Analogie zu der nordischen unternehmerischen und maritimen Kultur zu bilden, in der die Metallurgie zuerst übernommen wurde. Wie wurde dieser nördliche Randbereich „Bronzezeit“ und welche Folgen hatte seine Inklusion? Verschiedene Skalen - von lokal bis bronzezeitlich-global, überkreuzen sich, wie sich zeigt, im Hortfund von Pile und auch in vergleichbaren Fundorten in der Nähe und Ferne. Um $c$. 2000 BC reisten Metalle und andere Waren entlang wohletablierter lokaler, regionaler und überregionaler Netzwerke, die sogar die Britischen Inseln und die Aunjetitzer Knotenpunkte im Mittelelbe-Saale-Gebiet einschlossen. Zuhause in Skandinavien boten Metall und metall-bezogene Kultur einen vergleichsweisen Vorteil, wenn es um den lokalen Wettbewerb um Einfluss und Führung ging. Das transkulturelle Globale wurde lokal strategisch angeeignet, wobei die Erfindung von Tradition als wichtigste Strategie eingesetzt wurde. Der erste 
Metallboom verursachte Friktion und langsamen sozialen Wandel, weniger soziale Revolution. Der tatsächliche Kipppunkt kam 1600-1500 BC, als die nahezu vollentwickelte NBA entstand, durch die Auseinandersetzung mit einer erheblich erweiterten Welt. Zu dieser Zeit waren große Mengen an Metall im Umlauf. Aus Sicht des nichturbanen Nordens brachte diese beispiellose Expansion der Welt neue Möglichkeiten, aber wahrscheinlich auch tiefe soziale Spannungen. So durchdrangen die Folgen der Übernahme der Metallurgie die Gesellschaft und die Konnektivität auf allen Ebenen, selbst an den Rändern der bronzezeitlichen Welt.

\section{RESUMEN}

Los inicios de la Edad del Bronce- una visión escalar desde la periferia de la globalización, por Helle Vandkilde

Este artículo se basa en la formación de la rica y socialmente compleja Edad del Bronce Nórdica (NBA), c. 20001500 BC, aplicando una metodología escalar y empleando el entrepôt y el yacimiento con evidencias tempranas del trabajo del metal de Pile en Scania como punto de partida. En relación a la Edad del Bronce como un ejemplo antiguo de globalización, la isla de Melanesia a las afueras del mundo globalizado contemporáneo es inicialmente examinada para aportar un análogo a la cultura nórdica pionera y marítima en la que la metalurgia fue inicialmente adoptada. ¿Cómo este extremo septentrional adopta la "Edad del Bronce" y qué impacto tuvo su inclusión? Diferentes escalas, desde lo local a lo global de la Edad del Bronce se entrecruzaron en Pile, así como en sitios similares cercanos y más alejados. En torno al c. $2000 \mathrm{BC}$, los metales y otros productos básicos viajaban a través de redes bien establecidas a nivel local, regional y supra-regional, las cuales incorporaban las Islas Británicas y Únětician en la zona media del Elba-Saale. En el ámbito escandinavo, el metal y las culturas relacionadas con el metal aportaron una ventaja comparativa ya que propiciaron la competición por la navegación local y por el dominio de la influencia y liderazgo. La globalización transcultural fue apropiada estratégicamente a nivel local, utilizando la reinvención de la tradición como estrategia local. El primer auge del metal causó fricciones y escasas modificaciones sociales más que una revolución social. El verdadero punto de inflexión se produjo en el 1600-1500 BC cuando surgió la NBA, a través del compromiso con un mundo considerablemente más expandido. En este momento, grandes cantidades de metal estaban en circulación. Vista desde el norte no urbano, esta expansión sin precedentes trajo nuevas oportunidades pero también profundas tensiones sociales. Por lo tanto, los efectos de adoptar la metalurgia impregnaron la sociedad y las conexiones a todos los niveles, incluso con las zonas más perimetrales del mundo de la Edad del Bronce. 